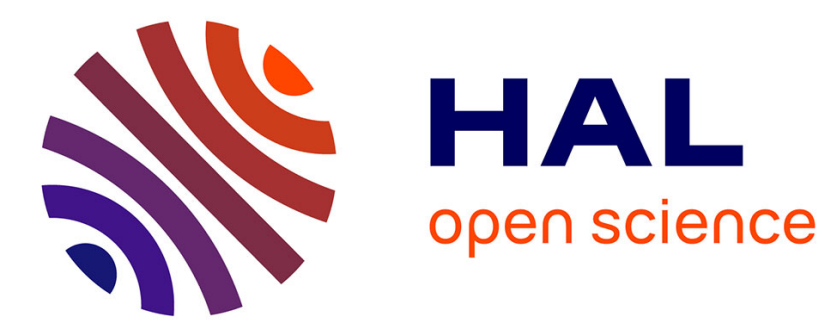

\title{
Effects of deep brain stimulation on balance and gait in patients with Parkinson's disease: A systematic neurophysiological review
}

Antoine Collomb-Clerc, Marie-Laure Welter

\section{- To cite this version:}

Antoine Collomb-Clerc, Marie-Laure Welter. Effects of deep brain stimulation on balance and gait in patients with Parkinson's disease: A systematic neurophysiological review. Neurophysiologie Clinique = Clinical Neurophysiology, 2015, 45 (4-5), pp.371-388. 10.1016/j.neucli.2015.07.001 . hal-01198838

\section{HAL Id: hal-01198838 \\ https: / hal.sorbonne-universite.fr/hal-01198838}

Submitted on 14 Sep 2015

HAL is a multi-disciplinary open access archive for the deposit and dissemination of scientific research documents, whether they are published or not. The documents may come from teaching and research institutions in France or abroad, or from public or private research centers.
L'archive ouverte pluridisciplinaire $\mathbf{H A L}$, est destinée au dépôt et à la diffusion de documents scientifiques de niveau recherche, publiés ou non, émanant des établissements d'enseignement et de recherche français ou étrangers, des laboratoires publics ou privés. 
Effects of deep brain stimulation on balance and gait in patients with Parkinson's disease: a systematic neurophysiological review

Antoine Collomb-Clerc, ${ }^{1,2,3,4,5}$ Marie-Laure Welter, MD, PhD.1,2,3,4,5

\section{Affiliations:}

1 AP-HP, Hôpital de la Salpêtrière, Département de Neurologie, F-75013 Paris, France; 2 Inserm, U1127, F-75013 Paris, France; 3 Sorbonne Universités, UPMC Univ Paris 06, UMRS 1127 F-75013 Paris, France; 2; 4 CNRS, UMR 7225, ICM, F-75013 Paris, France ; 5 Institut du Cerveau et de la Moelle épinière, ICM, F-75013, Paris, France; 5

Correspondence: ML Welter, Département de Neurologie, Bâtiment Paul Castaigne, Groupe Hospitalier Pitié-Salpêtrière, 47-83 bd de l'Hôpital, 75013 Paris, France., Tel: +33142161950, Fax: +33142161958, E-mail address: marie-laure.welter@psl.aphp.fr

Statistics: Title including spaces: 130 characters; Abstract: 209 words, Text: 5010 words, 17 pages, 4 Tables, 2 Figures, 139 References. 


\section{Summary}

Deep brain stimulation (DBS) of the subthalamic nucleus and internal globus pallidus deep brain stimulation provides an efficient treatment for the alleviation of motor signs in patients with Parkinson's disease. The effects of DBS on gait and balance disorders are less successful and may even lead to an aggravation of freezing of gait and imbalance. The identification of a substantia nigra pars reticulata (SNr)-mesencephalic locomotor region (MLR) network in the control of locomotion and postural control and of its dysfunction/lesion in PD patients with gait and balance disorders led to suggestion that DBS should be targeting the SNr and the pedunculopontine nucleus (part of the MLR) for PD patients with these disabling axial motor signs. However, the clinical results to date have been disappointing. In this review, we discuss the effects of DBS of these basal ganglia and brainstem structures on the neurophysiological parameters of gait and balance control in PD patients. Overall, the data suggest that both STN and GPi-DBS improve gait parameters and quiet standing postural control in PD patients, but have no effect or may even aggravate dynamic postural control, in particular with STN-DBS. Conversely, DBS of the SNr and PPN has no effect on gait parameters but improves anticipatory postural adjustments and gait postural control.

Keywords: Deep brain stimulation, gait, balance, Parkinson's disease

\section{Résumé}

La stimulation cérébrale profonde du noyau sous-thalamique (NST) ou du globus pallidum interne (GPi) représente un traitement efficace des troubles moteurs de la maladie de Parkinson. Les effets de la stimulation cérébrale profonde (SCP) sur les troubles de la marche et de l'équilibre sont moins probants avec parfois une aggravation post-opératoire du freezing de la marche et/ou des chutes. L'identification du circuit 
substantia nigra pas reticulata (SNr) -région locomotrice mésencéphalique (RLM), qui comprend le noyau pédunculopontin (NPP) comme ayant un rôle majeur dans le contrôle postural et la locomotion et de leur dysfonctionnement/lésion chez les patients parkinsoniens souffrant de troubles de la marche et de l'équilibre a permis d'envisager la SCP de ces régions cérébrales pour améliorer ces signes moteurs invalidants. Toutefois, les résultats cliniques ont été assez décevants. Dans cette revue, nous rapportons les effets de la SCP des ganglions de la base et du NPP sur les paramètres neurophysiologiques de la marche et du contrôle postural chez les patients parkinsoniens. En moyenne, la SCP du NST et du GPi améliore les paramètres locomoteurs et le contrôle postural en position statique, mais semble avoir peu ou pas d'effet sur le contrôle postural dynamique avec peut-être une aggravation, en particulier avec la SCP-NST. Inversement, la SCP de la SNr ou du PPN ne modifie pas les paramètres locomoteurs mais pourrait améliorer les ajustements posturaux anticipatoires et le contrôle postural dynamique.

Mots-clés: Stimulation cérébrale profonde, marche, équilibre, posture, maladie de Parkinson 


\section{Introduction}

In 1987, high frequency stimulation of the thalamus was first proposed as a treatment for patients with tremor [7]. In accordance with experimental data obtained in animals models of Parkinson's disease (PD) [8], deep brain stimulation of the internal part of the globus pallidus (GPi-DBS), one of the major basal ganglia outputs, and subthalamic nucleus (STN-DBS) was employed for the treatment of PD and proved an efficient means of improving parkinsonian symptoms and alleviating levodopa-induced motor complications [111], with in addition a significant decrease of the dopaminergic drug treatment with STN-DBS [135]. Whereas the efficacy of DBS on segmental motor symptoms, i.e. rigidity, tremor and peripheral akinesia, is well established, its effect on axial disability remains controversial [36]. Published data mainly report an improvement of posture, gait and balance control after GPi or STN-DBS, with a greater improvement with STN-DBS providing that these symptoms were responsive to levodopa treatment before surgery $[36,102,130]$. However, the effects of DBS on balance (postural instability) and gait tend to decrease with time [23,38,105]. Moreover, some authors suggest that DBS may induce or aggravate freezing of gait and postural instability with falls in PD patients with DBS [46], but also in non-parkinsonian patients [139]. The role of stimulation parameter settings, in particular the frequency of stimulation has been suspected, freezing of gait being reported to be improved with low frequency STN stimulation $(60-80 \mathrm{~Hz})[88,103,138]$.

Besides the loss of dopaminergic nigrostriatal neurons, the neuropathological hallmark of PD, the role of additional brain dysfunction and/or lesions in the occurrence of balance and gait disorders has been recently pointed out. In PD patients, a loss of cholinergic neurons in the pedunculopontine nucleus (PPN), in the mesencephalic tegmentum, has been reported in fallers PD patients, with a decrease in thalamic 
cholinesterase activity [12,13,60,67]. In normal and parkinsonian monkeys lesioning cholinergic neurons in the PPN induces gait and postural deficits resistant to levodopa treatment $[51,67]$. In line with these experimental data, low frequency PPN stimulation, thought to increase neuronal activity, has been tested in a few patients to improve freezing of gait and falls resistant to levodopa treatment and/or STN-DBS with disappointing and controversial results. In open label studies, PPN-DBS improved gait and balance in patients previously operated for STN-DBS, but also parkinsonian symptoms $[69,121]$. These first results have not been consistently confirmed in doubleblind assessments $[42,91,133]$. However, a subjective improvement in the number of falls or freezing episodes has been frequently reported [42,127,133]. Lastly, high frequency stimulation of the substantia nigra pars reticulata ( $\mathrm{SNr}$ ), the other major basal ganglia output, has also been recently tested in PD patients to alleviate gait and balance disorders $[25,132]$. The combination of STN and SNr-DBS might specifically improve freezing of gait, whereas balance impairment remains unchanged [132].

In this review, we summarise the effects of DBS on neurophysiological parameters of balance and gait in PD patients. For this purpose, we first briefly describe the different DBS targets used in PD patients from an anatomical and functional point of view in relationship with known neural structures and networks involved in balance and gait control in humans. We then report the changes induced by DBS from a neurophysiological point of view on these two distinct, but interconnected, motor processes. 


\section{Deep brain targets and neural pathways for gait and balance control in human}

Since the early experiments performed in invertebrate animals that revealed the predominant role of spinal cord central pattern generators (CPG), various brain cortical and subcortical areas have been identified as playing a major role in the control of gait and balance/posture in mammals. In mammals, cortical-basal ganglia-brainstem circuits modulate the central pattern generators (CPG) (see for review 95) that activate the organised and synchronised activation of forelimb muscles. In humans, the role of the CPG is still debated, gait being viewed as a higher-level motor activity (Figure 1).

At the subcortical level, in animals, postural muscle tone changes and/or locomotion can be induced by electrical or chemical modulation of the STN area, the brainstem reticular formation or mesencephalic locomotor region (MLR) that comprises PPN and the cuneiform nuclei (CN), the substantia nigra pars reticulata (SNr) and the cerebellum. Unilateral injection of GABAergic agents, producing functional lesions of the STN, induce postural asymmetry but not locomotion [33], whereas irreversible lesions produce both postural asymmetry and increased locomotor activity [2] . In both decerebrate cats and monkeys, electrical stimulation of the STN area generates locomotor activity while the animals' feet are in contact with a moving treadmill belt $[34,52]$. In freely moving rats, STN neuronal activity increases during locomotion, with some neural responses being related to the initiation and the termination of gait [116]. All in all, these data suggest that the STN is involved in postural control and locomotion. Similarly, electrical stimulation of the MLR or antagonist GABAergic agents injections induce suppression of muscle tone changes in forelimb muscles when performed into the caudal and medial part of the MLR, namely the PPN, and trigger quadrupedal locomotion when performed in its rostral and lateral part, namely the cuneiform nucleus (CN) $[34,90,123,125]$. These effects are abolished by concomitant electrical stimulation 
of the SNr. When the SNr is electrically stimulated, postural muscle tone changes are generated and a delay in the initiation of locomotor activity is observed, with an interruption of walking at high stimulation intensities. These effects are abolished by the inactivation of the MLR (mainly in the PPN) [124]. This highlights the major role of the SNr-MLR system in promoting gait and postural control in animals, in particular for the automatic regulation of postural muscle tone and rhythmic limb movements during locomotion [124]. Finally, the MLR is thought to: 1) activate and control the level of activity of the CPGs, 2) control balance during gait, 3) adapt the on-going movement to external perturbations and 4) coordinate locomotion with other motor actions [96]. Beside its connection with the SNr, the PPN is widely connected with the basal ganglia system, in particular the STN and the parafascicular and centre-median (Pf-CM) of the thalamus, but also with the globus pallidus and the striatum. The PPN is also connected to the primary motor and premotor cortices, the supplementary motor area (SMA) and the frontal eye field (FEF). In the cerebellum, irreversible lesions produce abnormal locomotor pattern and imbalance, more specifically when performed in the vermis [134]. At the cortical level, the primary motor cortex has been reported to be mainly involved in complex gait tasks that require precise forelimb positioning (obstacle avoidance or direction changes) and the SMA for balance control during locomotion $[6,32]$. The posterior parietal cortex is also necessary to plan and execute gait pattern adaptations $[6,84]$.

In human, the use of SPECT, TEP or NIRS allows real gait cortico-subcortical networks imagery. An activation of the premotor, primary sensorimotor, prefrontal, SMA, anterior cingulate, parahippocampal, fusiform and lingual gyri, precuneus and cuneus, superior parietal and visual cortices, cerebellar vermis with extension to the MLR and the thalamus has been reported after and/or during real gait $[49,72,87]$. At the 
cortical level, perturbation of static balance induces dorsolateral prefrontal (DLPFC), medial precentral, SMA and posterior parietal cortex activation [85]. Mental imagery of standing position, swaying on a balance board, gait or running have been recently examined by using functional MRI or PET in healthy subjects. These studies demonstrated that imagining 1) standing in a static position induced preferentially vestibular, visual and somatosensory cortices, median thalamus, pallidum, striatum, dorsal pons, MLR and cerebellum vermis activation [63], 2) swaying on a balance board induced preferentially SMA, dorsal premotor, middle cingulate cortex, superior parietal lobule, putamen, ventrolateral thalamus, MLR and cerebellum vermis activation $[43,68$, 3) gait induced preferentially SMA, parahippocampical, fusigorm and lingual gyri, precuneus and cuneus, posterior cingulate and visual cortices, putamen, STN, MLR and cerebellar vermis and cortex activation with decreased activity in the vestibular and somatosensory cortices $[63,66,72,79]$ (Figure 1) and 4) running induced preferentially cerebellar cortex and MLR activation with less cortical activity [63]. Lastly, neuronal recordings performed in PD patients demonstrate that mental imagery of gait $[73,126]$, steps mimicking [99] and real gait [47] modulate MLR-PPN neuronal activity.

Finally, in humans and experimental animals, two distinct networks with : 1) the vermis-pons-MLR (lateral)-thalamus-vestibular-SMA-parietal posterior cortex and 2) the vermis-MLR (medial)-basal ganglia (putamen,STN)-fusiform, parahippocampic and sensorimotor cortices seem preferentially implicated in the control of balance and locomotion, respectively (Figure 1). In PD patients with gait, especially freezing of gait, and balance disorders these networks have been reported to be dysfunctional and/or lesioned, in particular the SMA, parietal posterior cortex, MLR and cerebellum with decreased cholinergic activity [11,44,56,112,114,119]. As previously briefly exposed, different structures of these two networks, i.e. the STN, GPi, SNr and MLR, have been 
targeted for DBS to treat motor disability, including gait and balance disorders, in PD patients. In the subsequent part of this article, we report on the effects of DBS on neurophysiological parameters of gait and balance in PD patients.

\section{Effects of deep brain stimulation on balance and gait control in PD patients}

Balance and gait control can be assessed in humans by the use of specialised devices that enable kinematic (motion capture system), biomechanical (force platform) and electromyographic (surface electrodes) recording during standing, gait initiation or walking, under various conditions (quiet or perturbed standing, eyes open or closed, spontaneous or fast gait, etc...). In PD patients, many studies have reported changes in these various parameters in the absence of DBS or medical drug treatment, and the effects of levodopa treatment on them. Since the advent of deep brain stimulation in PD patients, relatively few studies have specifically dealt with the effects of DBS on balance and gait control parameters.

\section{Effects of DBS on balance control}

Effects of DBS in the quiet standing position

\section{Body Position}

Since it was first described, it has been reported that PD patients show an abnormal flexed posture when standing [97]. By precisely assessing the inter-segmental coupling and electromyographic activity, it has been reported that this abnormal posture is related to an abnormally high inter-segmental stiffness (in particular between the trunk and hip segments) [81] and higher background EMG activity with cocontraction $[19,20,27,31]$. An increased inclination of trunk, thigh and shank with respect to the vertical, with a related significant increase of external mechanical 
moments acting at the hip and knee joints [27]. With levodopa treatment, all these parameters of standing body position are improved [20,27]. Similarly, STN-DBS reduces the forward trunk-bending with a trend toward a lower inclination of the thigh and significant decrease of the inclination of the shank, which induces a reduction of the mechanical moment at the hip and ankle. Leg muscles activity is also significantly reduced, with a similar effect on extensor and flexor groups [27]. Improvements are observed with both unilateral and bilateral STN-DBS $[27,81]$, although changes are found to be more robust with bilateral DBS [27].

\section{Centre of foot pressure displacement and velocity}

The major parameters recorded to describe static posture and standing position are generally assessed by the use of a force platform which records the centre of foot pressure (CoP) displacements and velocities in the anteroposterior (AP) and mediolateral (ML) directions during quiet stance. Although in normal subjects without postural instability during quiet standing the CoP is perpetually in movement, it exhibits slow and short CoP displacements contained in a restricted area, preferentially oriented in the sagittal direction [136]. Among the postural sway measures yielded from CoP, the CoP velocity has been suggested to be most sensitive for detecting changes in balance ability due to aging and/or neurological diseases $[80,108]$.

While in a standing position, PD patients as a result of their higher amplitude and faster upper and lower body displacements, AP and ML displacements and velocities of the CoP are increased to cover a large area. These abnormal parameters are frequently related to a history of falls and clinical imbalance 86. Both an abnormal anterior or posterior shift of the CoP average position has been reported in PD patients $[27,53]$. Dopaminergic replacement therapy appears ineffective in improving with these 
parameters and as been reported in some cases to aggravate the situation with an increase in CoP displacements and area covered (Table 1) [53,76,107]. The effect of DBS on these parameters remains controversial (Table 1). Some studies report an improvement with a reduction in the CoP displacements and velocities, close to control values with both STN-DBS and GPi-DBS [26,53,107 27], whereas others report an aggravation with an increase in swaying [81] or no effect $[76,93,94,128]$. The posterior shift of the CoP in the standing position is also reduced by STN-DBS [27,53], but not to within the normal range, however. More recently, in relation to the clinical observations of an improvement in axial signs with low frequency STN-DBS, the effects of low $(60 \mathrm{~Hz})$ versus high $(130 \mathrm{~Hz})$ frequency of STN-DBS on CoP displacements and velocities during standing have been examined. Whatever the STN-DBS frequency or voltage, no significant change in the CoP velocities and ML displacements have been observed, although there was a decrease (improvement) in the AP direction with low frequency stimulation [128]. Lastly, the combination of levodopa treatment and STN-DBS results in an average effect of the two treatments taken separately, which may correspond to an improvement or a worsening $[27,53,81]$.

\section{Centre of foot pressure frequency}

The increased stiffness and CoP velocities observed in PD patients lead to an increased CoP frequency in both AP and ML directions, in particular the $0.7-1.1 \mathrm{~Hz}$ range, with an asymmetrical mean CoP frequency between the two feet $[81,107,109,131]$. In addition, some patients exhibit a $5 \mathrm{~Hz}$ power peak corresponding to postural tremor. Both levodopa, GPi and STN-DBS restored the CoP frequency values to the normal range $[81,107,109,131]$ (Table 1). Conversely, the asymmetrical mean 
frequency between the feet experienced is increased with levodopa but reduced by STNDBS [107].

\section{Effects of DBS on perturbed standing position}

The sensory organization test is presumed to identify deficits in the processing of somatosensory, visual and vestibular information that contribute to dynamic postural control. The subject is placed on a force platform and by means of calibrated 'sway referencing' of the support surface and/or the visual surround, visual and somatosensory inputs are abolished creating sensory conflict situations. These conditions isolate the vestibular balance control, as well as stressing the adaptive responses of the central nervous system. In short, patients may display either an inability to make effective use of specific sensory systems, or inappropriate adaptive responses, resulting in the fallback use of less accurate sense(s). PD patients usually show difficulties in maintaining an upright stance when sensory feedback is limited, with increased sway [15], a reduced postural mean velocity and increased reaction times $[26,118]$. When the standing position is perturbed by an AP tilt or forward translation, PD patients are unable to move fast and react quickly enough to correct sudden perturbations, with increased and delayed destabilising medium and long latency response amplitudes resulting in an increase of the AP CoP displacements [10]. Finally, PD patients are unable to adapt their postural responses to functional demand with fixed gain [5]. Levodopa treatment has been reported to have no significant positive effect on these postural responses [10].

In PD patients, STN-DBS significantly improves postural control in the sensory deprived and incongruent conditions. The quality of postural sensorimotor strategies is improved, patient being able to provide better adapted responses to destabilisation with 
increased agonist muscle activity duration $[26,120]$, as well as during a rapid arm movement in standing position [9]. GPi-DBS also improves postural responses to platform perturbations [120]. The combination of STN-DBS and levodopa treatment induces a degradation of postural responses, whereas the combination of GPi-DBS and levodopa induces no such change [120].

Finally, conversely to that observed with levodopa treatment leading to a more or less severe degradation of static postural control, STN-DBS and GPi-DBS improve central integration of sensory feedback and reduce induced sensory conflicts $[15,120]$ with an improvement in the processing of the sensory and internally generated signals necessary for postural control.

\section{Effects of DBS on gait control}

Effects of DBS on the initiation of gait (Table 2)

In healthy subjects, gait initiation comprises two parts: the preparation phase and the execution phase. During the preparation phase, different anticipatory postural adjustments have been described before raising the swing foot from the floor [28, $54,131]$. From a biomechanical point of view, the CoP is first projected backward toward the swing leg (S1), then towards the heel of the stance leg (S2) to enable the contralateral foot to be raised from the ground and finally towards the tiptoe stance (S3). During this phase, the centre of mass (CoM) moves forward creating an AP disruption between the CoM and CoP positions. During the execution phase (swing phase), the vertical CoM velocity curve describes a V shape that corresponds to a forward fall that is restored before the foot hits the ground (braking index) $[14,134]$. Finally, just after the foot-contact, the CoP moves under the heel of the displaced foot, and then under the toe tips and so on... enabling the gait to smoothly progress $[54,136]$. 
In PD patients, in the absence of levodopa treatment, the APAs are perturbed with reduced AP and ML CoP displacement amplitude and velocity, longer duration and presence of atypical sequences of lateral and forward CoP displacements directed towards the stance leg $[21,50,54]$. The transition between the different phases (i.e. S1, S2, S3) is perturbed with high variability in the relative proportions of the 3 phases. These changes have been related to an abnormal interaction between the initial body fall and abnormal leg muscle baseline activity, i.e. persistent tonic activity in the triceps surae followed by activation of the antagonist tibialis anterior [28,54]. During the execution phase, the length and velocity of the first step are reduced with an increase in the double-stance duration [21]. Conversely, the cadence of the first step is not or mildly modified in PD patients, in comparison to age-matched controls [54]. The dopaminergic treatment improved APAs with a reduction of the APAs duration and an increase of the AP and ML CoP displacements and velocities $[21,106]$. The muscles activity pattern is also improved and the length and velocity of the first step significantly increased with levodopa treatment $[21,106]$. Conversely, the levodopa treatment does not significantly improve the balance control during the first step (as reflected by the braking index) $[24,129]$.

The effects of STN-DBS on APAs differed from a study to another. It seems that STN-DBS generally induces an increase in the AP CoP displacement during the APAs whereas no change or an increase in the ML direction is seen $[75,106,128]$. Its effect on the APAs duration is also unclear with either a decrease [27] or no significant change being found $[75,106,128]$. Bilateral STN-DBS generates an improvement in the leg muscular imbalance coupling with a restoration of near normal patterns with a clearer inhibition of the triceps surae along with a more intense and synchronised recruitment of the tibialis anterior [27](Figure 2). Interestingly, unilateral STN-DBS produces similar 
effects on the APAs of both the ipsi- and contralateral foot of the stimulated STN [27]. However, unilateral STN-DBS induces smaller changes in the AP and ML CoP directions compared to bilateral STN-DBS. The application of low-frequency (60 Hz) STN-DBS provoked no significant changes in the APAs in comparison to high-frequency $(130 \mathrm{~Hz})$, with an increased ML velocity during the S2 phase with both (low and high) frequencies at high voltages [128]. The combination of STN-DBS and levodopa treatment appears to improve both amplitude and duration of the APAs, that remain, however, significantly different from control values [106]. In addition to its positive effects on the APAs, STNDBS significantly increased the length and velocity of the first step, similarly to levodopa treatment $[25,27,75,106]$ (Figure 2). Decreasing frequency of STN-DBS has no significant impact on step length and velocity of the first step [128]. The balance control during the execution of the first step (braking control) is also improved with bilateral STN-DBS in relationship with an increased stance leg soleus muscle activity during the swing phase [25](Figure 2).

When applied in the GPi, DBS appears to have little or no impact on the APAs (amplitude, velocity, duration) [106] but provokes an improvement of transfer of the CoP under the support leg with decreased shoulder amplitude, increased ankle velocity and time displacement [29]. The length and velocity of the first step significantly increases with a reduction in the double-stance duration $[29,106]$. Up to now, the effects of SNr-DBS on the APAs has not been reported but an improvement of balance control during gait initiation (braking index) has been observed in some PD patients with no significant change in length and velocity of the first step [25]. Low frequency unilateral PPN-DBS has been reported to increase the CoP displacement and velocity during the S2 phase with no change in the APAs phase duration [82]. This change was not significant when compared to the no-levodopa treatment condition, however [82]. Lastly, bilateral 
PPN-DBS has been reported to significantly increase the ML CoP displacement during the APAs and decrease the double stance duration [133]. Conversely, the length and velocity of the first step were un-modified with PPN-DBS but increased after surgery, probably as a result of a lesioning effect [133].

\section{Effects of DBS on automatic gait}

In PD patients, in the absence of levodopa treatment, stride length and gait velocity are significantly lower than controls (reflecting gait hypokinesia) whereas the cadence has been generally reported unmodified or increased to compensate for the reduced length $[1,92]$. Other parameters have been also identified as of particular interest in PD patients: the stride-to-stride variability (or gait rhythm), the bilateral coordination of stepping and the double-stance duration, being related to freezing of gait and/or risk of falling [58,101]. Kinematic recordings also reveal a reduction in the angular excursion at leg joints, range of trunk torsion amplitude and lateral flexion, amplitude of arm and leg swing movements and forward bending of the trunk.

Both levodopa treatment and STN-DBS improve gait parameters with an increase in step length, gait velocity, angular leg excursion, reduced double-stance duration and normalisation of the leg muscles pattern $[1,22,35,39,40,70,76,89,104,122,137$ ] (Table 3). STN-DBS also reduces the spatial foot position asymmetry, stride-to-stride variability and inter-limb coordination, with a more physiological alternating gait cycle $[57,64]$. Decreasing frequency of STN-DBS has no or few significant impact on gait parameters [ $89,128]$. The combination of levodopa treatment and STN-DBS produces a greater increase in gait velocity $[35,40,57,78,122]$. When applied in the GPi, DBS has been reported to also significantly increase gait velocity and decrease the double-stance duration $[1,29]$, with also an increase or no change in step length, cadence and swing 
time (Table 4). PPN-DBS alone induces no significant change in the gait velocity or upper and lower limbs movements $[89,98]$ (Table 4). The combination of low frequency PPN (25 Hz) and STN (60 Hz) DBS seems to produce a higher increase in stride length and velocity than PPN or STN-DBS alone (with both 60 or $180 \mathrm{~Hz}$ ) [89]. 


\section{Discussion}

Both STN and GPi DBS improve gait parameters and quiet standing postural control in PD patients. Its effects on dynamic and gait postural control, including the APAs, are still controversial, with on average a tendency to aggravate postural control with STN-DBS and with either no change or a small positive effect with GPi-DBS. Conversely, SNr and PPNa-DBS lead to no change in gait parameters but tend to improve APAs and gait postural control.

From a clinical point of view, the effects of DBS on gait and postural control have mainly been examined in relationship with their levodopa response. From a neurophysiological point of view, levodopa treatment has been reported to be ineffective at improving static and dynamic postural control, and may even worsen some parameters $[10,24,48,81,107,120]$. However, it is effective at improving APAs and the parameters of gait kinematics and biomechanics, with the restoration of leg muscle activity patterns to normal levels $[24,27,106,128]$. These data suggest that STN-DBS and levodopa treatment have similar positive effects on neurophysiological parameters of gait and postural control, with an additional improvement of gait velocity when both are combined $[35,78,122,137]$. This is in line with the strong relationship observed between the improvement of axial motor signs with levodopa treatment before surgery and STNDBS after surgery $[3,36,102,135]$. Axial motor sign improvement is recognized as the major preoperative clinical parameter predicting best post-operative outcome [135]. Beside improvement, as well as with levodopa treatment, a disruption of APAs and both significant decreases and increases in the sway amplitude during quiet stance have been described with STN-DBS, with no or little effect on the poor compensation for external destabilising postural perturbation $[61,81,104]$. The APAs disruption and postural degradation could participate in both the occurrence or aggravation of freezing of gait 
after surgery, as suggested for non-operated PD patients [62], and the increased fall rate reported in patients with STN-DBS but not with GPi-DBS [46]. These data suggest that STN-DBS operates on gait and postural control, at least partly, through the functional restoration of the dopaminergic systems $[16,17]$. How STN-DBS restores the dopaminergic transmission within the BG circuitry is not clearly established. In animals rendered parkinsonian and PD patients, STN-DBS decreases the increased STN neuronal activity, burst-type activity and abnormal oscillations [30], as well as the levodopa replacement therapy $[74,77]$. STN-DBS also provokes changes in other output and input structures with anti- and orthodromic activation resulting in a 'global' effect within the entire cortico-striato-pallido-thalamo-cortical system, with pattern regularisation and decreased abnormal oscillations [113]. However, some differences exist between the effects of STN-DBS and levodopa. Indeed, the dynamic and gait postural control have been reported to improve with STN-DBS whereas levodopa has no positive impact $[25,120]$. Moreover, the combination of STN-DBS and levodopa treatment induces greater increase in gait velocity compared to STN or levodopa treatment alone [35,41]. Conversely, a lower effect of levodopa treatment on APAs has been reported when combined with STN-DBS [106]. These observations suggest that the STN is per se involved in gait and balance control in human. In line with this hypothesis, electrical stimulation of the STN in normal animals induces locomotion [34]. In PD patients, modifying the electrical parameters or the site of the STN-DBS induced significant changes in dynamic postural and gait parameters. An increase AP CoP velocity during the unloading phase of gait initiation, regularisation of the cadence, improvement in leg coordination with reduced step length and velocity variability have been reported with lower frequency STN-DBS $(60 \mathrm{~Hz})[37,88,128]$ and greater increase in step length and velocity with dorsal versus ventral STN-DBS [65,83]. Lastly, recent imaging studies using 
fMRI in healthy humans also show that the STN is activated during mental imagery of gait [72] and that PD patients with freezing of gait presented a disruption of the functional coupling between the STN (but also the GPi ) and the sensorimotor and frontoparietal cortical regions [117].

The effects of GPi-DBS on postural and gait control are less clearly established. In the few studies reported, GPi-DBS seems to have little or no effect on static and dynamic postural control, with an improvement or no change in the APAs $[29,106]$ but a significant increase in stride length, step length and velocity during active walking $[1,71]$, but to a lesser extent than with STN-DBS $[1,106]$. Comparison of levodopa treatment and GPi-DBS revealed no clear relationship between the effects of these two treatments. This observation and the fact that in PD patients with GPi-DBS levodopa replacement therapy could not be reduced after surgery $[45,110]$ suggest that GPi-DBS may act differentially on the cortico-BG-cortical network with no 'dopaminergic like' effect, maybe by the modulation of the descending pathways to the MLR. When DBS is applied in the SNr or in the PPN, dynamic postural control is improved with no significant impact on gait parameters $[25,98,133]$. These data suggest that 1 ) the GPi and the SNr, the two main basal ganglia output structures, are preferentially involved in locomotion and postural control, respectively and 2) the PPN is also preferentially involved in postural control, depending on their level of activity. This hypothesis is in line with data obtained in animals and humans. In normal primates, injections of GABAergic agents in the GPi induce dystonic and choreiform limb movements whereas it produces severe axial postural anomalies when injected in the $\mathrm{SNr}$ [18]. In decerebrate cats, local inhibition of the SNr by GABAergic agonist agents (eg muscimol) induces locomotion and lowers leg muscle tone with the reverse effects when excitatory high frequency electrical stimulation is applied $[123,124]$. In parkinsonian monkeys, SNr 
lesions produce a reversal of body orientation, with no improvement in bradykinesia [59]. In PD patients, high frequency SNr also leads to axial motor changes with an improvement of clinical gait and postural stability $[25,132]$ and an increase in dynamic postural control [25]. As the SNr projects GABAergic inputs to the MLR, the effects of the SNr-DBS on gait and postural control may be related, at least partly, to a modulation of the MLR-PPN activity. In PD patients, low frequency PNN-DBS does not affect gait parameters but improves postural control $[98,133]$. This could result from the partial restoration of the cholinergic pathway to the basal ganglia, thalamus and to the descending pathways to the spinal cord 55. Indeed, PPN-DBS generates cerebral blood flow increases in the thalamus, cerebellum and midbrain region [4] and restores the $\mathrm{H}$ reflex [100]. PPN-DBS also improves the connectivity between the PPN and the SMA shown to be defective in PD patients with freezing of gait [115].

Finally, all these data suggest that two main subcortical networks are involved in gait (gait length, velocity and rhythmicity) and balance (static and dynamic posture) control in humans, the first comprising mainly the subthalamo-pallidal-MLR pathway and the second the subthalamo-nigro-pedunculopontine pathway. These two subcortical networks are functionally connected with sensorimotor and frontoparietal cortices and a dysfunction across these two coordinated neural networks has been reported in PD patients with gait and balance disorders. Future studies are needed to further explore the specific role of these two networks in gait and balance control, in particular, highresolution analyses with functional or metabolic brain imagery combined with precise neurophysiological assessment of balance and postural control. 


\section{Figure Legends}

Figure 1. Anatomical structures and pathways involved in the control of gait and balance in human. Left: schematic representation of anatomical and cortico-subcortical networks; Right: Cortical and subcortical activations during mental imagery of gait in comparison to mental imagery of object movement (red: gait versus movement; blue: movement versus gait) in a healthy subject. Note an activation of the bilateral medial primary motor cortex (legs and trunk motor region), bilateral parietal cortex, cerebellum and the MLR. AC: Anterior Cingulate, BG: basal ganglia, CBL: cerebellar cortex, CBM: cerebellar vermis, FEF: frontal eye field, Fus: fusiform gyrus, GPe: external globus pallidus, GPi: internal globus pallidus, M1: primary motor cortex, MLR: mesencephalic locomotor region, PF: prefrontal cortex, pHip: parahippocampic gyrus, PreM: premotor cortex, SMA: supplementary motor area, RF: reticular formation, STN: subthalamic nucleus, Put: putamen, PPN: pedunculupontine nucleus, SNr: substantia nigras pars reticulata; S: somatosensorial cortex, Thal: Thalamus, V: visual cortices.

\section{Figure 2. Effects of levodopa treatment and STN-DBS on biomechanical parameters of gait initiation in a Parkinsonian patient.}

Curves represent from top to bottom, the mediolateral (ML) and anteroposterior (AP) CoP displacements, antero-posterior and vertical (V) CoM velocity. The mediolateral displacement of the CoP enables the measurement of the lateral displacement of the CoP before foot-off (mediolateral APAs) and the step width (W). The anteroposterior displacement of the CoP enables the measurement of the posterior displacement of the CoP before the foot-off (anteroposterior APAs) and the step length (L). With the anteroposterior velocity of the CoM, the maximum forward velocity $(\mathrm{Vm})$ is measured at the end of the first step. The CoM vertical velocity curve enables the measurement of the position of V1 (negative peak of the CoM vertical velocity) and V2 (CoM vertical velocity 
at the time of foot-contact) and the braking index ((V1-V2)/V1*100). Here, before surgery both wihtout (OFF) and with levodopa treatment (ON), the fall of the CoM is stopped when the foot touches the ground, i.e. no braking occurs (V1=V2). After surgery, with STN-DBS, vertical velocity of the CG describes a V shape indicating that an active braking occurs. Tibialis anterior (TA) and Soleus muscles activity of the stance and swing legs. t0: time of the first biomechanical event; HO = heel-off of the swing leg; F01 = foot-off of the swing leg; FC = foot-contact of the swing leg; FO2 = foot-off of the stance leg.

\section{Acknowledgments}

We thank Eric Bardinet for providing the MR images.

\section{Disclosure of interest}

The authors declare that they have no conflicts of interest concerning this article. 


\section{References}

1. Allert N, Volkmann J, Dotse S, Hefter H, Sturm V, Freund HJ: Effects of bilateral pallidal or subthalamic stimulation on gait in advanced Parkinson's disease. Mov Disord 16:1076-1085., 2001

2. Andren PE, Levin ED, Liminga U, Gunne L: Behavioral and neurochemical consequences of ibotenic acid lesion in the subthalamic nucleus of the common marmoset. Brain Res Bull 36:301-307, 1995

3. Bakker M, Esselink RA, Munneke M, Limousin-Dowsey P, Speelman HD, Bloem BR: Effects of stereotactic neurosurgery on postural instability and gait in Parkinson's disease. Mov Disord 19:1092-1099, 2004

4. Ballanger B, Lozano AM, Moro E, van Eimeren T, Hamani C, Chen R, et al: Cerebral blood flow changes induced by pedunculopontine nucleus stimulation in patients with advanced Parkinson's disease: a [(15)0] H2O PET study. Hum Brain Mapp 30:3901-3909, 2009

5. Beckley DJ, Bloem BR, Remler MP: Impaired scaling of long latency postural reflexes in patients with Parkinson's disease. Electroencephalogr Clin Neurophysiol 89:22-28., 1993

6. Beloozerova IN, Sirota MG, Swadlow HA, Orlovsky GN, Popova LB, Deliagina TG: Activity of different classes of neurons of the motor cortex during postural corrections. J Neurosci 23:7844-7853, 2003

7. Benabid AL, Pollak P, Louveau A, Henry S, de Rougemont J: Combined (thalamotomy and stimulation) stereotactic surgery of the VIM thalamic nucleus for bilateral Parkinson disease. Appl Neurophysiol 50:344-346, 1987

8. Bergman H, Wichmann T, Karmon B, DeLong MR: The primate subthalamic nucleus. II. Neuronal activity in the MPTP model of parkinsonism. J 
9. Bleuse S, Delval A, Blatt JL, Derambure P, Destee A, Defebvre L: Effect of bilateral subthalamic nucleus deep brain stimulation on postural adjustments during arm movement. Clin Neurophysiol 122:2032-2035, 2011

10. Bloem BR, Beckley DJ, van Dijk JG, Zwinderman AH, Remler MP, Roos RA: Influence of dopaminergic medication on automatic postural responses and balance impairment in Parkinson's disease. Mov Disord 11:509-521., 1996

11. Bohnen NI, Frey KA, Studenski S, Kotagal V, Koeppe RA, Constantine GM, et al: Extra-nigral pathological conditions are common in Parkinson's disease with freezing of gait: an in vivo positron emission tomography study. Mov Disord 29:1118-1124, 2014

12. Bohnen NI, Frey KA, Studenski SA, Kotagal V, Koeppe RA, Scott PJ, et al: Gait speed in Parkinson disease correlates with cholinergic degeneration. Neurology Oct 29;81:1611-1616, 2013

13. Bohnen NI, Muller ML, Koeppe RA, Studenski SA, Kilbourn MA, Frey KA, et al: History of falls in Parkinson disease is associated with reduced cholinergic activity. Neurology 73:1670-1676, 2009

14. Breniere Y, Bril B: Why does the child walk in falling while the adult falls in walking? C. R. Acad. Sci. Paris 307:617-622, 1988

15. Bronte-Stewart HM, Minn AY, Rodrigues K, Buckley EL, Nashner LM: Postural instability in idiopathic Parkinson's disease: the role of medication and unilateral pallidotomy. Brain 125:2100-2114, 2002

16. Brown P, Mazzone P, Oliviero A, Altibrandi MG, Pilato F, Tonali PA, et al: Effects of stimulation of the subthalamic area on oscillatory pallidal activity in Parkinson's disease. Exp Neurol 188:480-490, 2004 
17. Brown RG, Dowsey PL, Brown P, Jahanshahi M, Pollak P, Benabid AL, et al: Impact of deep brain stimulation on upper limb akinesia in Parkinson's disease. Ann Neurol 45:473-488, 1999

18. Burbaud P, Bonnet B, Guehl D, Lagueny A, Bioulac B: Movement disorders induced by gamma-aminobutyric agonist and antagonist injections into the internal globus pallidus and substantia nigra pars reticulata of the monkey. Brain Res 780:102-107, 1998

19. Burleigh A, Horak F: Influence of instruction, prediction, and afferent sensory information on the postural organization of step initiation. J Neurophysiol 4:1619-1630, 1996

20. Burleigh A, Horak F, Nutt J, Frank J: Levodopa reduces muscle tone and lower extremity tremor in Parkinson's disease. Can J Neurol Sci 22:280-285., 1995

21. Burleigh-Jacobs A, Horak FB, Nutt JG, Obeso JA: Step initiation in Parkinson's disease: influence of levodopa and external sensory triggers. Mov Disord 12:206-215., 1997

22. Carpinella I, Crenna P, Marzegan A, Rabuffetti M, Rizzone M, Lopiano L, et al: Effect of L-dopa and subthalamic nucleus stimulation on arm and leg swing during gait in Parkinson's Disease. Conf Proc IEEE Eng Med Biol Soc 2007:6665-6668, 2007

23. Castrioto A, Lozano AM, Poon YY, Lang AE, Fallis M, Moro E: Ten-Year Outcome of Subthalamic Stimulation in Parkinson Disease: A Blinded Evaluation. Arch Neurol, 2011

24. Chastan N, Do MC, Bonneville F, Torny F, Bloch F, Westby GW, et al: Gait and balance disorders in Parkinson's disease: impaired active braking of the fall of centre of gravity. Mov Disord 24:188-195, 2009 
25. Chastan N, Westby GW, Yelnik J, Bardinet E, Do MC, Agid Y, et al: Effects of nigral stimulation on locomotion and postural stability in patients with Parkinson's disease. Brain 132:172-184, 2009

26. Colnat-Coulbois S, Gauchard GC, Maillard L, Barroche G, Vespignani H, Auque J, et al: Bilateral subthalamic nucleus stimulation improves balance control in Parkinson's disease. J Neurol Neurosurg Psychiatry 76:780-787, 2005

27. Crenna P, Carpinella I, Rabuffetti M, Rizzone M, Lopiano L, Lanotte M, et al: Impact of subthalamic nucleus stimulation on the initiation of gait in Parkinson's disease. Exp Brain Res 172:519-532, 2006

28. Crenna P, Frigo C: A motor programme for the initiation of forward-oriented movements in humans. J Physiol 437:635-653., 1991

29. Defebvre LJ, Krystkowiak P, Blatt JL, Duhamel A, Bourriez JL, Perina M, et al: Influence of pallidal stimulation and levodopa on gait and preparatory postural adjustments in Parkinson's disease. Mov Disord 17:76-83., 2002

30. Deniau JM, Degos B, Bosch C, Maurice N: Deep brain stimulation mechanisms: beyond the concept of local functional inhibition. Eur J Neurosci 32:1080-1091, 2010

31. Dietz V: Reflex behavior and programming in Parkinson's disease. Adv Neurol 60:375-380., 1993

32. Drew T, Jiang W, Widajewicz W: Contributions of the motor cortex to the control of the hindlimbs during locomotion in the cat. Brain Res Brain Res Rev 40:178191., 2002

33. Dybdal D, Gale K: Postural and anticonvulsant effects of inhibition of the rat subthalamic nucleus. J Neurosci 20:6728-6733, 2000

34. Eidelberg E, Walden JG, Nguyen LH: Locomotor control in macaque monkeys. Brain 104:647-663, 1981 
35. Faist M, Xie J, Kurz D, Berger W, Maurer C, Pollak P, et al: Effect of bilateral subthalamic nucleus stimulation on gait in Parkinson's disease. Brain 124:15901600., 2001

36. Fasano A, Aquino CC, Krauss JK, Honey CR, Bloem BR: Axial disability and deep brain stimulation in patients with Parkinson disease. Nat Rev Neurol 11:98-110, 2015

37. Fasano A, Herzog J, Seifert E, Stolze H, Falk D, Reese R, et al: Modulation of gait coordination by subthalamic stimulation improves freezing of gait. Mov Disord 26:844-851, 2011

38. Fasano A, Romito LM, Daniele A, Piano C, Zinno M, Bentivoglio AR, et al: Motor and cognitive outcome in patients with Parkinson's disease 8 years after subthalamic implants. Brain 133:2664-2676, 2010

39. Ferrarin M, Carpinella I, Rabuffetti M, Rizzone M, Lopiano L, Crenna P: Unilateral and bilateral subthalamic nucleus stimulation in Parkinson's disease: effects on EMG signals of lower limb muscles during walking. IEEE Trans Neural Syst Rehabil Eng 15:182-189, 2007

40. Ferrarin M, Lopiano L, Rizzone M, Lanotte M, Bergamasco B, Recalcati M, et al: Quantitative analysis of gait in Parkinson's disease: a pilot study on the effects of bilateral sub-thalamic stimulation. Gait Posture 16:135-148, 2002

41. Ferrarin M, Rizzone M, Bergamasco B, Lanotte M, Recalcati M, Pedotti A, et al: Effects of bilateral subthalamic stimulation on gait kinematics and kinetics in Parkinson's disease. Exp Brain Res 160:517-527, 2005

42. Ferraye MU, Debu B, Fraix V, Goetz L, Ardouin C, Yelnik J, et al: Effects of pedunculopontine nucleus area stimulation on gait disorders in Parkinson's disease. Brain 133:205-214, 2010 
43. Ferraye MU, Debu B, Heil L, Carpenter M, Bloem BR, Toni I: Using motor imagery to study the neural substrates of dynamic balance. PLoS One 9:e91183, 2014

44. Fling BW, Cohen RG, Mancini M, Carpenter SD, Fair DA, Nutt JG, et al: Functional reorganization of the locomotor network in Parkinson patients with freezing of gait. PLoS One 9:e100291, 2014

45. Follett KA: Comparison of pallidal and subthalamic deep brain stimulation for the treatment of levodopa-induced dyskinesias. Neurosurg Focus 17:E3, 2004

46. Follett KA, Weaver FM, Stern M, Hur K, Harris CL, Luo P, et al: Pallidal versus subthalamic deep-brain stimulation for Parkinson's disease. N Engl J Med 362:2077-2091, 2010

47. Fraix V, Bastin J, David O, Goetz L, Ferraye M, Benabid AL, et al: Pedunculopontine nucleus area oscillations during stance, stepping and freezing in Parkinson's disease. PLoS One 8:e83919, 2013

48. Frank JS, Horak FB, Nutt J: Centrally initiated postural adjustments in parkinsonian patients on and off levodopa. J Neurophysiol 84:2440-2448, 2000

49. Fukuyama H, Ouchi Y, Matsuzaki S, Nagahama Y, Yamauchi H, Ogawa M, et al: Brain functional activity during gait in normal subjects: a SPECT study. Neurosci Lett 228:183-186., 1997

50. Gantchev N, Viallet F, Aurenty R, Massion J: Impairment of posturo-kinetic coordination during initiation of forward oriented stepping movements in parkinsonian patients. Electroencephalogr Clin Neurophysiol 101:110-120., 1996

51. Grabli D, Karachi C, Folgoas E, Monfort M, Tande D, Clark S, et al: Gait disorders in parkinsonian monkeys with pedunculopontine nucleus lesions: a tale of two systems. J Neurosci 33:11986-11993, 2013 
52. Grillner S, Shik ML: On the descending control of the lumbosacral spinal cord from the "mesencephalic locomotor region". Acta Physiol Scand 87:320-333, 1973

53. Guehl D, Dehail P, de Seze MP, Cuny E, Faux P, Tison F, et al: Evolution of postural stability after subthalamic nucleus stimulation in Parkinson's disease: a combined clinical and posturometric study. Exp Brain Res 170:206-215, 2006

54. Halliday SE, Winter DA, Frank JS, Patla AE, Prince F: The initiation of gait in young, elderly, and Parkinson's disease subjects. Gait Posture 8:8-14., 1998

55. Hamani C, Moro E, Lozano AM: The pedunculopontine nucleus as a target for deep brain stimulation. J Neural Transm 118:1461-1468, 2011

56. Hanakawa T, Katsumi Y, Fukuyama H, Honda M, Hayashi T, Kimura J, et al: Mechanisms underlying gait disturbance in Parkinson's disease: a single photon emission computed tomography study. Brain 122:1271-1282., 1999

57. Hausdorff JM, Gruendlinger L, Scollins L, O'Herron S, Tarsy D: Deep brain stimulation effects on gait variability in Parkinson's disease. Mov Disord 24:1688-1692, 2009

58. Hausdorff JM, Schaafsma JD, Balash Y, Bartels AL, Gurevich T, Giladi N: Impaired regulation of stride variability in Parkinson's disease subjects with freezing of gait. Exp Brain Res 149:187-194, 2003

59. Henderson JM, Stanic D, Tomas D, Patch J, Horne MK, Bourke D, et al: Postural changes after lesions of the substantia nigra pars reticulata in hemiparkinsonian monkeys. Behav Brain Res 160:267-276, 2005

60. Hirsch EC, Graybiel AM, Duyckaerts C, Javoy-Agid F: Neuronal loss in the pedunculopontine tegmental nucleus in Parkinson disease and in progressive supranuclear palsy. Proc Natl Acad Sci U S A 84:5976-5980, 1987 
61. Horak FB, Frank J, Nutt J: Effects of dopamine on postural control in parkinsonian subjects: scaling, set, and tone. J Neurophysiol 75:2380-2396., 1996

62. Jacobs JV, Nutt JG, Carlson-Kuhta P, Stephens M, Horak FB: Knee trembling during freezing of gait represents multiple anticipatory postural adjustments. Exp Neurol 215:334-341, 2009

63. Jahn K, Deutschlander A, Stephan T, Kalla R, Hufner K, Wagner J, et al: Supraspinal locomotor control in quadrupeds and humans. Prog Brain Res 171:353-362, 2008

64. Johnsen EL, Mogensen PH, Sunde NA, Ostergaard K: Improved asymmetry of gait in Parkinson's disease with DBS: gait and postural instability in Parkinson's disease treated with bilateral deep brain stimulation in the subthalamic nucleus. Mov Disord 24:590-597, 2009

65. Johnsen EL, Sunde N, Mogensen PH, Ostergaard K: MRI verified STN stimulation site--gait improvement and clinical outcome. Eur J Neurol 17:746-753, 2010

66. Karachi C, Andre A, Bertasi E, Bardinet E, Lehericy S, Bernard FA: Functional parcellation of the lateral mesencephalus. J Neurosci 32:9396-9401, 2012

67. Karachi C, Grabli D, Bernard FA, Tande D, Wattiez N, Belaid H, et al: Cholinergic mesencephalic neurons are involved in gait and postural disorders in Parkinson disease. J Clin Invest 120:2745-2754, 2010

68. Karim HT, Sparto PJ, Aizenstein HJ, Furman JM, Huppert TJ, Erickson KI, et al: Functional MR imaging of a simulated balance task. Brain Res 1555:20-27, 2014

69. Khan S, Gill SS, Mooney L, White P, Whone A, Brooks DJ, et al: Combined pedunculopontine-subthalamic stimulation in Parkinson disease. Neurology 78:1090-1095, 2012 
70. Krystkowiak P, Blatt JL, Bourriez JL, Duhamel A, Perina M, Blond S, et al: Effects of subthalamic nucleus stimulation and levodopa treatment on gait abnormalities in Parkinson disease. Arch Neurol 60:80-84., 2003

71. Krystkowiak P, Blatt JL, Bourriez JL, Duhamel A, Perina M, Kemoun G, et al: Chronic bilateral pallidal stimulation and levodopa do not improve gait in the same way in Parkinson's disease: a study using a video motion analysis system. J Neurol 248:944-949, 2001

72. la Fougere C, Zwergal A, Rominger A, Forster S, Fesl G, Dieterich M, et al: Real versus imagined locomotion: a [18F]-FDG PET-fMRI comparison. Neuroimage 50:1589-1598, 2010

73. Lau B, Welter ML, Belaid H, Fernandez Vidal S, Bardinet E, Grabli D, et al: The integrative role of the pedunculopontine nucleus in human gait. Brain 138:12841296, 2015

74. Levy R, Ashby P, Hutchison WD, Lang AE, Lozano AM, Dostrovsky JO: Dependence of subthalamic nucleus oscillations on movement and dopamine in Parkinson's disease. Brain 125:1196-1209, 2002

75. Liu W, McIntire K, Kim SH, Zhang J, Dascalos S, Lyons KE, et al: Bilateral subthalamic stimulation improves gait initiation in patients with Parkinson's disease. Gait Posture 23:492-498, 2006

76. Liu W, McIntire K, Kim SH, Zhang J, Dascalos S, Lyons KE, et al: Quantitative assessments of the effect of bilateral subthalamic stimulation on multiple aspects of sensorimotor function for patients with Parkinson's disease. Parkinsonism Relat Disord 11:503-508, 2005

77. Lozano AM, Lang AE, Levy R, Hutchison W, Dostrovsky J: Neuronal recordings in Parkinson's disease patients with dyskinesias induced by apomorphine. Ann Neurol 47:S141-146., 2000 
78. Lubik S, Fogel W, Tronnier V, Krause M, Konig J, Jost WH: Gait analysis in patients with advanced Parkinson disease: different or additive effects on gait induced by levodopa and chronic STN stimulation. J Neural Transm 113:163-173, 2006

79. Malouin F, Richards CL, Jackson PL, Dumas F, Doyon J: Brain activations during motor imagery of locomotor-related tasks: a PET study. Hum Brain Mapp 19:4762., 2003

80. Masani K, Vette AH, Kouzaki M, Kanehisa H, Fukunaga T, Popovic MR: Larger center of pressure minus center of gravity in the elderly induces larger body acceleration during quiet standing. Neurosci Lett 422:202-206, 2007

81. Maurer C, Mergner T, Xie J, Faist M, Pollak P, Lucking CH: Effect of chronic bilateral subthalamic nucleus (STN) stimulation on postural control in Parkinson's disease. Brain 126:1146-1163, 2003

82. Mazzone P, Paoloni M, Mangone M, Santilli V, Insola A, Fini M, et al: Unilateral deep brain stimulation of the pedunculopontine tegmental nucleus in idiopathic Parkinson's disease: effects on gait initiation and performance. Gait Posture 40:357-362, 2014

83. McNeely ME, Hershey T, Campbell MC, Tabbal SD, Karimi M, Hartlein JM, et al: Effects of deep brain stimulation of dorsal versus ventral subthalamic nucleus regions on gait and balance in Parkinson's disease. J Neurol Neurosurg Psychiatry 82:1250-1255, 2011

84. McVea DA, Pearson KG: Object avoidance during locomotion. Adv Exp Med Biol 629:293-315, 2009

85. Mihara M, Miyai I, Hatakenaka M, Kubota K, Sakoda S: Role of the prefrontal cortex in human balance control. Neuroimage 43:329-336, 2008 
86. Mitchell SL, Collins JJ, De Luca CJ, Burrows A, Lipsitz LA: Open-loop and closedloop postural control mechanisms in Parkinson's disease: increased mediolateral activity during quiet standing. Neurosci Lett 197:133-136, 1995

87. Miyai I, Tanabe HC, Sase I, Eda H, Oda I, Konishi I, et al: Cortical mapping of gait in humans: a near-infrared spectroscopic topography study. Neuroimage 14:11861192,2001

88. Moreau C, Defebvre L, Destee A, Bleuse S, Clement F, Blatt JL, et al: STN-DBS frequency effects on freezing of gait in advanced Parkinson disease. Neurology 71:80-84, 2008

89. Moreau C, Defebvre L, Devos D, Marchetti F, Destee A, Stefani A, et al: STN versus PPN-DBS for alleviating freezing of gait: toward a frequency modulation approach? Mov Disord 24:2164-2166, 2009

90. Mori S, Sakamoto T, Ohta Y, Takakusaki K, Matsuyama K: Site-specific postural and locomotor changes evoked in awake, freely moving intact cats by stimulating the brainstem. Brain Res 505:66-74, 1989

91. Moro E, Hamani C, Poon YY, Al-Khairallah T, Dostrovsky JO, Hutchison WD, et al: Unilateral pedunculopontine stimulation improves falls in Parkinson's disease. Brain 133:215-224, 2010

92. Morris ME, Iansek R, Matyas TA, Summers JJ: The pathogenesis of gait hypokinesia in Parkinson's disease. Brain 117:1169-1181., 1994

93. Nantel J, McDonald JC, Bronte-Stewart H: Effect of medication and STN-DBS on postural control in subjects with Parkinson's disease. Parkinsonism Relat Disord 18:285-289, 2012

94. Nilsson MH, Fransson PA, Jarnlo GB, Magnusson M, Rehncrona S: The effects of high frequency subthalamic stimulation on balance performance and fear of falling in patients with Parkinson's disease. J Neuroeng Rehabil 6:13, 2009 
95. Nutt JG, Horak FB, Bloem BR: Milestones in gait, balance, and falling. Mov Disord 26:1166-1174, 2011

96. Orlovsky GN: Gravistatic postural control in simpler systems. Curr Opin Neurobiol 1:621-627, 1991

97. Parkinson J: An esssay on the shaking palsy. Sherwood, London, 1817

98. Peppe A, Pierantozzi M, Chiavalon C, Marchetti F, Caltagirone C, Musicco M, et al: Deep brain stimulation of the pedunculopontine tegmentum and subthalamic nucleus: effects on gait in Parkinson's disease. Gait Posture 32:512-518, 2010

99. Piallat B, Chabardes S, Torres N, Fraix V, Goetz L, Seigneuret E, et al: Gait is associated with an increase in tonic firing of the sub-cuneiform nucleus neurons. Neuroscience 158:1201-1205, 2009

100. Pierantozzi M, Palmieri MG, Galati S, Stanzione P, Peppe A, Tropepi D, et al: Pedunculopontine nucleus deep brain stimulation changes spinal cord excitability in Parkinson's disease patients. J Neural Transm 115:731-735, 2008

101. Plotnik M, Giladi N, Dagan Y, Hausdorff JM: Postural instability and fall risk in Parkinson's disease: impaired dual tasking, pacing, and bilateral coordination of gait during the "ON" medication state. Exp Brain Res 210:529-538, 2011

102. Potter-Nerger M, Volkmann J: Deep brain stimulation for gait and postural symptoms in Parkinson's disease. Mov Disord 28:1609-1615, 2013

103. Ricchi V, Zibetti M, Angrisano S, Merola A, Arduino N, Artusi CA, et al: Transient effects of $80 \mathrm{~Hz}$ stimulation on gait in STN DBS treated PD patients: a 15 months follow-up study. Brain Stimul 5:388-392, 2012

104. Rizzone M, Ferrarin M, Pedotti A, Bergamasco B, Bosticco E, Lanotte M, et al: High-frequency electrical stimulation of the subthalamic nucleus in Parkinson's disease: kinetic and kinematic gait analysis. Neurol Sci 23:S103-104., 2002 
105. Rizzone MG, Fasano A, Daniele A, Zibetti M, Merola A, Rizzi L, et al: Long-term outcome of subthalamic nucleus DBS in Parkinson's disease: From the advanced phase towards the late stage of the disease? Parkinsonism Relat Disord, 2014

106. Rocchi L, Carlson-Kuhta P, Chiari L, Burchiel KJ, Hogarth P, Horak FB: Effects of deep brain stimulation in the subthalamic nucleus or globus pallidus internus on step initiation in Parkinson disease: laboratory investigation. J Neurosurg 117:1141-1149, 2012

107. Rocchi L, Chiari L, Cappello A, Gross A, Horak FB: Comparison between subthalamic nucleus and globus pallidus internus stimulation for postural performance in Parkinson's disease. Gait Posture 19:172-183, 2004

108. Rocchi L, Chiari L, Cappello A, Horak FB: Identification of distinct characteristics of postural sway in Parkinson's disease: a feature selection procedure based on principal component analysis. Neurosci Lett 394:140-145, 2006

109. Rocchi L, Chiari L, Horak FB: Effects of deep brain stimulation and levodopa on postural sway in Parkinson's disease. J Neurol Neurosurg Psychiatry 73:267274,2002

110. Rodriguez-Oroz MC, Gorospe A, Guridi J, Ramos E, Linazasoro G, RodriguezPalmero M, et al: Bilateral deep brain stimulation of the subthalamic nucleus in Parkinson's disease. Neurology 55:S45-51, 2000

111. Rodriguez-Oroz MC, Obeso JA, Lang AE, Houeto JL, Pollak P, Rehncrona S, et al: Bilateral deep brain stimulation in Parkinson's disease: a multicentre study with 4 years follow-up. Brain 128:2240-2249, 2005

112. Rubino A, Assogna F, Piras F, Di Battista ME, Imperiale F, Chiapponi C, et al: Does a volume reduction of the parietal lobe contribute to freezing of gait in Parkinson's disease? Parkinsonism Relat Disord 20:1101-1103, 2014 
113. Santaniello S, McCarthy MM, Montgomery EB, Jr., Gale JT, Kopell N, Sarma SV: Therapeutic mechanisms of high-frequency stimulation in Parkinson's disease and neural restoration via loop-based reinforcement. Proc Natl Acad Sci U S A 112:E586-595, 2015

114. Schweder PM, Hansen PC, Green AL, Quaghebeur G, Stein J, Aziz TZ: Connectivity of the pedunculopontine nucleus in parkinsonian freezing of gait. Neuroreport 21:914-916, 2010

115. Schweder PM, Joint C, Hansen PC, Green AL, Quaghebeur G, Aziz TZ: Chronic pedunculopontine nucleus stimulation restores functional connectivity. Neuroreport 21:1065-1068, 2010

116. Shi LH, Luo F, Woodward DJ, Chang JY: Neural responses in multiple basal ganglia regions during spontaneous and treadmill locomotion tasks in rats. Exp Brain Res 157:303-314, 2004

117. Shine JM, Matar E, Ward PB, Bolitho SJ, Gilat M, Pearson M, et al: Exploring the cortical and subcortical functional magnetic resonance imaging changes associated with freezing in Parkinson's disease. Brain 136:1204-1215, 2013

118. Shivitz N, Koop MM, Fahimi J, Heit G, Bronte-Stewart HM: Bilateral subthalamic nucleus deep brain stimulation improves certain aspects of postural control in Parkinson's disease, whereas medication does not. Mov Disord 21:1088-1097, 2006

119. Snijders AH, Leunissen I, Bakker M, Overeem S, Helmich RC, Bloem BR, et al: Gaitrelated cerebral alterations in patients with Parkinson's disease with freezing of gait. Brain 134:59-72, 2011

120. St George RJ, Carlson-Kuhta P, Burchiel KJ, Hogarth P, Frank N, Horak FB: The effects of subthalamic and pallidal deep brain stimulation on postural responses in patients with Parkinson disease. J Neurosurg 116:1347-1356, 2012 
121. Stefani A, Lozano AM, Peppe A, Stanzione P, Galati S, Tropepi D, et al: Bilateral deep brain stimulation of the pedunculopontine and subthalamic nuclei in severe Parkinson's disease. Brain 130:1596-1607, 2007

122. Stolze H, Klebe S, Poepping M, Lorenz D, Herzog J, Hamel W, et al: Effects of bilateral subthalamic nucleus stimulation on parkinsonian gait. Neurology 57:144-146., 2001

123. Takakusaki K, Habaguchi T, Ohtinata-Sugimoto J, Saitoh K, Sakamoto T: Basal ganglia efferents to the brainstem centers controlling postural muscle tone and locomotion: a new concept for understanding motor disorders in basal ganglia dysfunction. Neuroscience 119:293-308., 2003

124. Takakusaki K, Oohinata-Sugimoto J, Saitoh K, Habaguchi T: Role of basal gangliabrainstem systems in the control of postural muscle tone and locomotion. Prog Brain Res 143:231-237, 2004

125. Takakusaki K, Saitoh K, Harada H, Kashiwayanagi M: Role of basal gangliabrainstem pathways in the control of motor behaviors. Neurosci Res 50:137151,2004

126. Tattersall TL, Stratton PG, Coyne TJ, Cook R, Silberstein P, Silburn PA, et al: Imagined gait modulates neuronal network dynamics in the human pedunculopontine nucleus. Nat Neurosci 17:449-454, 2014

127. Thevathasan W, Cole MH, Graepel CL, Hyam JA, Jenkinson N, Brittain JS, et al: A spatiotemporal analysis of gait freezing and the impact of pedunculopontine nucleus stimulation. Brain 135:1446-1454, 2012

128. Vallabhajosula S, Haq IU, Hwynn N, Oyama G, Okun M, Tillman MD, et al: Lowfrequency versus high-frequency subthalamic nucleus deep brain stimulation on postural control and gait in Parkinson's disease: a quantitative study. Brain Stimul 8:64-75, 2015 
129. Vaugoyeau M, Viel S, Assaiante C, Amblard B, Azulay JP: Impaired vertical postural control and proprioceptive integration deficits in Parkinson's disease. Neuroscience 146:852-863, 2007

130. Vercruysse S, Vandenberghe W, Munks L, Nuttin B, Devos H, Nieuwboer A: Effects of deep brain stimulation of the subthalamic nucleus on freezing of gait in Parkinson's disease: a prospective controlled study. J Neurol Neurosurg Psychiatry 85:871-877, 2014

131. Vrancken AM, Allum JH, Peller M, Visser JE, Esselink RA, Speelman JD, et al: Effect of bilateral subthalamic nucleus stimulation on balance and finger control in Parkinson's disease. J Neurol 252:1487-1494, 2005

132. Weiss D, Walach M, Meisner C, Fritz M, Scholten M, Breit S, et al: Nigral stimulation for resistant axial motor impairment in Parkinson's disease? A randomized controlled trial. Brain 136:2098-2108, 2013

133. Welter ML, Demain A, Ewenczyk C, Czernecki V, Lau B, El Helou A, et al: PPNaDBS for gait and balance disorders in Parkinson's disease: a double-blind, randomised study. J Neurol, 2015

134. Welter ML, Do MC, Chastan N, Torny F, Bloch F, du Montcel ST, et al: Control of vertical components of gait during initiation of walking in normal adults and patients with progressive supranuclear palsy. Gait Posture 26:393-399, 2007

135. Welter ML, Houeto JL, Tezenas du Montcel S, Mesnage V, Bonnet AM, Pillon B, et al: Clinical predictive factors of subthalamic stimulation in Parkinson's disease. Brain 125:575-583, 2002

136. Winter DA: Human balance and posture control during standing and walking. Gait Posture 3:193-214, 1995

137. Xie J, Krack P, Benabid AL, Pollak P: Effect of bilateral subthalamic nucleus stimulation on parkinsonian gait. J Neurol 248:1068-1072, 2001 
138. Xie T, Vigil J, MacCracken E, Gasparaitis A, Young J, Kang W, et al: Low-frequency stimulation of STN-DBS reduces aspiration and freezing of gait in patients with PD. Neurology 84:415-420, 2015

139. Zauber SE, Watson N, Comella CL, Bakay RA, Metman LV: Stimulation-induced parkinsonism after posteroventral deep brain stimulation of the globus pallidus internus for craniocervical dystonia. J Neurosurg 110:229-233, 2009 
Table 1. Effects of subthalamic nucleus deep brain stimulation on neurophysiological parameters of static postural control in PD patients

\begin{tabular}{|c|c|c|c|c|c|c|c|c|c|c|c|c|c|}
\hline \multirow{2}{*}{\multicolumn{3}{|c|}{\begin{tabular}{|l|} 
\\
n. of patients
\end{tabular}}} & \begin{tabular}{|l} 
Rocchi et al. \\
2002
\end{tabular} & $\begin{array}{l}\text { Maurer et al. } \\
2003\end{array}$ & $\begin{array}{l}\text { Rocchi et al. } \\
2004\end{array}$ & $\begin{array}{l}\text { Vrancken et al. } \\
2005\end{array}$ & $\begin{array}{l}\text { Colnat-Coulbois et al. } \\
2005\end{array}$ & $\begin{array}{l}\text { Liu et al. } \\
2005\end{array}$ & $\begin{array}{l}\text { Crenna et al. } \\
2006\end{array}$ & $\begin{array}{l}\text { Guehl et al. } \\
2006\end{array}$ & $\begin{array}{l}\text { Nilsson et al. } \\
2009\end{array}$ & $\begin{array}{l}\text { Nantel et al. } \\
2012\end{array}$ & $\begin{array}{l}\text { Vallabhajosula et al. } \\
2015\end{array}$ \\
\hline & & & 6 & 8 & 5 & 14 & 12 & 11 & 10 & & & & \\
\hline \multicolumn{3}{|l|}{\begin{tabular}{|l|l|} 
Age (yrs) \\
\end{tabular}} & $61 \pm 9$ & $48 \pm 8$ & $60 \pm 6$ & $50 \pm 8$ & $59(54-67)$ & $54 \pm 9$ & $60 \pm 5$ & $57 \pm 12$ & $66(59-69)$ & $60 \pm 8$ & $62 \pm 9$ \\
\hline \multirow{2}{*}{\multicolumn{3}{|c|}{\begin{tabular}{|l} 
Disease duration (yrs) \\
Time after surgery (months)
\end{tabular}}} & $16 \pm 5$ & $13 \pm 7$ & $19 \pm 2$ & $15 \pm 4$ & $112(10-14)$ & $14 \pm 6$ & $17 \pm 6$ & $13 \pm 4$ & $18(10-22)$ & $10 \pm 5$ & $14 \pm 4$ \\
\hline & & & 6 & $15 \pm 11$ & 6 & $18 \pm 12$ & 6 & $16 \pm 10$ & $10 \pm 7$ & 3 & $37(15-70)$ & $10 \pm 2$ & $35 \pm 24$ \\
\hline \multirow{2}{*}{ Before surgery } & LD & DBS & & & & & & & & & & & \\
\hline & OFF & 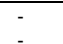 & 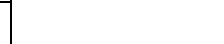 & & & & $\begin{array}{l}\mathrm{X} \\
\mathrm{X}\end{array}$ & $\begin{array}{l}X \\
x\end{array}$ & & $\begin{array}{l}x \\
x\end{array}$ & & $\begin{array}{l}X \\
x\end{array}$ & \\
\hline \multirow{4}{*}{ After surgery } & OFF & OFF & $\mathrm{x}$ & $\mathrm{x}$ & $\mathrm{x}$ & & & $\mathrm{x}$ & $\mathrm{x}$ & $\mathrm{x}$ & $\mathrm{x}$ & & $\mathrm{x}$ \\
\hline & OFF & ON & $\mathrm{x}$ & $\mathrm{x}$ & $\mathrm{x}$ & & & $\mathrm{x}$ & $\mathrm{x}$ & $\mathrm{x}$ & $\mathrm{X}$ & $\mathrm{x}$ & $\mathrm{x}$ \\
\hline & ON & OFF & $\int_{y}^{x}$ & $\mathrm{x}$ & $\mathrm{x}$ & $\mathrm{x}$ & $\mathrm{x}$ & $\mathrm{x}$ & $\mathrm{x}$ & $\mathrm{x}$ & & $\mathrm{x}$ & \\
\hline & $\begin{array}{l}\text { ON } \\
\text { OFF }\end{array}$ & ON & & & $\mathrm{x}$ & $\mathrm{X}$ & $\begin{array}{l}X \\
49(44-58)\end{array}$ & $\begin{array}{l}X \\
41 \pm 7\end{array}$ & $x$ & $\frac{x}{37 \pm 7}$ & & $\frac{x}{36+13}$ & \\
\hline \multirow{4}{*}{ UPDRS III } & ONF & - & & & & & $\begin{array}{l}49(44-58) \\
15(11-22) \\
\end{array}$ & $26 \pm 10$ & & $11 \pm 6$ & & $\begin{array}{l}6 \pm \pm 9 \\
18 \pm 9\end{array}$ & \\
\hline & OFF & OFF & $58 \pm 26$ & $49 \pm 16$ & $64 \pm 6$ & & & & $62 \pm 11$ & $35 \pm 11$ & $41(35-84)$ & & $29 \pm 2$ \\
\hline & OFF & ON & $36 \pm 17$ & $7 \pm 3$ & $40 \pm 13$ & & & $26 \pm 10$ & $21 \pm 10$ & $13 \pm 5$ & $22(11-31)$ & $11 \pm 8$ & $24 \pm 2$ \\
\hline & & $\begin{array}{l}\text { OFF } \\
\text { ON }\end{array}$ & $\begin{array}{l}26 \pm 8 \\
25+2\end{array}$ & $\begin{array}{l}14 \pm 7 \\
4 \pm 2\end{array}$ & $\begin{array}{l}26 \pm 5 \\
20+6\end{array}$ & $\begin{array}{l}51 \pm 10 \\
31+8\end{array}$ & $140(9-19)$ & $21+9$ & $\begin{array}{l}24 \pm 14 \\
13+7\end{array}$ & $\begin{array}{l}12 \pm 7 \\
6+4\end{array}$ & & $8+7$ & (No difference 60 vs $>100$ \\
\hline \multirow[t]{3}{*}{\begin{tabular}{|l|} 
DOPA effect \\
\end{tabular}} & \multicolumn{2}{|c|}{ No change } & & PF tilt response & & & & CoP ML/AP D & & $\begin{array}{l}\text { CoP D } \\
\text { CoP Area }\end{array}$ & & & \\
\hline & \multicolumn{2}{|c|}{ Increase } & & $\begin{array}{l}\text { CoP/UB/LB D \& \&ar) } \\
\text { CoP/UB/LB ML D (\&var) } \\
\text { CoP/UB/LB AP D \& \& var) } \\
\text { CoP D RMS } \\
\text { CoP A } \\
\text { CoP/UB/LB D low Frequency } \\
\text { CoP D mild Frequency } \\
\text { UB-LB coupling } \\
\end{array}$ & $\begin{array}{l}\text { CoP AP\&ML D } \\
\text { CoP Velocity } \\
\text { CoP RMS }\end{array}$ & & & & & & & $\begin{array}{l}\text { CoP ML\&AP D } \\
\text { CoP ML\&AP Velocity }\end{array}$ & \\
\hline & \multicolumn{2}{|c|}{ Decrease } & & $\begin{array}{l}\text { CoP/UB/LB Velocity } \\
\text { CoP/UB/UL D high Frequency }\end{array}$ & CoP Frequency & & & & & CoP Post shift & & & \\
\hline \multirow[t]{3}{*}{\begin{tabular}{|l} 
Effects of STN- \\
DBS
\end{tabular}} & \multicolumn{2}{|c|}{ No change } & CoP D RMS asymmetry & PF tilt response & & CoP ML/AP Velocity & $\begin{array}{l}\text { CoP AP sway (Eyes } \\
\text { open\&close) }\end{array}$ & CoP ML/AP D & $\begin{array}{l}\text { CoP L shift } \\
\text { Thigh inclination } \\
\text { Knee moment }\end{array}$ & & CoP ML/AP D & $\begin{array}{l}\text { CoP ML/AP D RMS } \\
\text { CoP ML/AP Velocity }\end{array}$ & $\begin{array}{l}\text { CoP ML/AP D, RMS } \\
\text { CoP Amplitude } \\
\text { CoP ML/AP Velocity } \\
\& \text { RMS } \\
\text { (No difference } 60 \text { vs > } 100 \\
\text { Hz DBS-STN) }\end{array}$ \\
\hline & \multicolumn{2}{|c|}{ Increase } & & $\begin{array}{l}\text { CoP/UB/LB D. } \\
\text { CoP/UB/LB ML D. } \\
\text { CoP/UB/LB AP D. } \\
\text { CoPA } \\
\text { CoP/UB/LB D low Frequency } \\
\text { CoP D mild Frequency } \\
\text { CoP/UB/LB V low Frequency } \\
\text { UB-LB coupling } \\
\end{array}$ & & & & & & & & & \\
\hline & \multicolumn{2}{|c|}{ Decrease } & \begin{tabular}{|l} 
CoP Velocity \\
CoP V RMS asymmetry. \\
CoP D RMS \\
CoP D Frequency \\
CoP D Frequency \\
RMS asymmetry
\end{tabular} & $\begin{array}{l}\text { CoP/UB/LB Velocity } \\
\text { CoP/UB/UL D high Frequency }\end{array}$ & $\begin{array}{l}\text { CoP Velocity } \\
\text { CoP Frequency } \\
\text { CoP AP\&ML D } \\
\text { CoP RMS }\end{array}$ & $\begin{array}{l}\text { CoP ML/AP D } \\
\text { CoP high Frequency }\end{array}$ & $\begin{array}{l}\text { CoP area } \\
\text { CoP ML D } \\
\text { (Eyes open\&close) }\end{array}$ & & $\begin{array}{l}\text { CoP P shift } \\
\text { Trunk inclination } \\
\text { Shank inclination } \\
\text { Hip moment } \\
\text { Ankle moment } \\
\text { Limb extensors RMS } \\
\text { Limb flexor RMS }\end{array}$ & $\begin{array}{l}\text { CoP Post shift } \\
\text { CoP D } \\
\text { CoP Area }\end{array}$ & & & \\
\hline
\end{tabular}

Values are mean \pm SD or mean (range); AP: anteroposterior; CoP: centre of foot pressure; D: displacement; DBS: deep brain stimulation; F: frequency; LB: lower body; LD: levodopa; ML: mediolateral; RMS: root

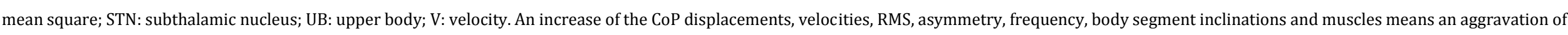
static postural control. An increase in the upper-body/lower-body coupling means an improvement of body position. 
Table 2. Effects of deep brain stimulation on neurophysiological parameters of gait initiation in PD patients

\begin{tabular}{|c|c|c|c|c|c|c|c|c|c|c|c|c|}
\hline & & & \begin{tabular}{|l|} 
Liu et al. \\
2005\&2006 \\
\end{tabular} & $\begin{array}{l}\text { Crenna et al. } \\
2006\end{array}$ & $\begin{array}{l}\text { Chastan et al. } \\
2009\end{array}$ & $\begin{array}{l}\text { Rocchi et al. } \\
2012\end{array}$ & $\begin{array}{l}\text { Vallabhajosula et al. } \\
2015\end{array}$ & $\begin{array}{l}\text { Defebvre et al. } \\
2002\end{array}$ & $\begin{array}{l}\text { Rocchi et al. } \\
2012\end{array}$ & \begin{tabular}{|l|} 
Chastan et al. \\
2009
\end{tabular} & \begin{tabular}{|l} 
Mazzone et al. \\
2014
\end{tabular} & $\begin{array}{l}\text { Welter et al. } \\
2015\end{array}$ \\
\hline \multicolumn{3}{|l|}{ Target } & STN & STN & STN & STN & STN & GPi & GPi & SNr & Unilateral PPN & Bilateral PPN \\
\hline \multicolumn{3}{|l|}{$N$ of patients } & 11 & 10 & 7 & 15 & 19 & 7 & 14 & & & \\
\hline \multirow{2}{*}{\multicolumn{3}{|c|}{\begin{tabular}{|l|} 
Age (yrs) \\
Disease duration (yrs)
\end{tabular}}} & $54(41-66)$ & $60 \pm 5$ & $61 \pm 7$ & $61 \pm 6$ & $62 \pm 9$ & $58 \pm 11$ & $61 \pm 8$ & $61.0 \pm 7$ & $60 \pm 7$ & $62.0 \pm 11.0$ \\
\hline & & & $13 \pm 5$ & $17 \pm 6$ & $18 \pm 4$ & $12 \pm 5$ & $14 \pm 4$ & $15 \pm 3$ & $13 \pm 10$ & $18 \pm 4$ & & $15.8 \pm 5.9$ \\
\hline \multicolumn{3}{|c|}{ Time after surgery (months) } & $16 \pm 10$ & $10 \pm 7$ & $44 \pm 20$ & 6 & $39 \pm 24$ & & 6 & $44 \pm 20$ & 12 & $4-6$ \\
\hline \multirow{2}{*}{\multicolumn{3}{|c|}{\begin{tabular}{lll}
\multirow{3}{*}{ Before surgery } & LD & \multicolumn{1}{c}{ DBS } \\
\cline { 2 - 4 } & OFF
\end{tabular}}} & & & & & & & & & & \\
\hline & & & & & & $\begin{array}{l}\mathrm{x} \\
\mathrm{x}\end{array}$ & & $\begin{array}{l}\mathrm{x} \\
\mathrm{x}\end{array}$ & $\begin{array}{l}\mathrm{x} \\
\mathrm{x}\end{array}$ & $x_{x}^{x}$ & & $\begin{array}{l}\mathrm{x} \\
\mathrm{x}\end{array}$ \\
\hline \multirow{3}{*}{ After surgery } & $\begin{array}{ll}\text { OFF } & 0\end{array}$ & OFF & $\mathrm{X}$ & $\mathrm{X}$ & $\mathrm{X}$ & $\mathrm{X}$ & $\mathrm{X}$ & $x$ & $\frac{1}{X}$ & $\frac{A}{x}$ & & $\frac{A}{x}$ \\
\hline & OFF 0 & ON & $\mathrm{x}$ & $\mathrm{x}$ & $\mathrm{x}$ & $\mathrm{x}$ & $\mathrm{x}$ & $\mathrm{x}$ & $\mathrm{x}$ & $\frac{\mathrm{x}}{\mathrm{x}}$ & $\mathrm{x}$ & $\mathrm{x}$ \\
\hline & $\begin{array}{ll}\text { ON } & 0 \\
\text { ON } & 0\end{array}$ & $\begin{array}{l}\text { OFF } \\
\text { ON }\end{array}$ & $\begin{array}{l}x \\
x\end{array}$ & $\begin{array}{l}X \\
x\end{array}$ & $\mathrm{X}$ & $\begin{array}{l}x \\
x\end{array}$ & & $\begin{array}{l}\mathrm{x} \\
\mathrm{x}\end{array}$ & $\begin{array}{l}\mathrm{x} \\
\mathrm{x}\end{array}$ & $\mathrm{x}$ & $\mathrm{x}$ & $\begin{array}{l}\mathrm{x} \\
\mathrm{x}\end{array}$ \\
\hline \multirow[t]{5}{*}{ UPDRS III } & OFF - & - & & & $31 \pm 11$ & $49 \pm 12$ & & $\begin{array}{l}30 \pm 6 \\
19+6\end{array}$ & $\begin{array}{l}51 \pm 18 \\
29+14\end{array}$ & & & $48.5 \pm 9.7$ \\
\hline & $\begin{array}{ll}\text { OFF } & 0\end{array}$ & OFF & $41 \pm 7$ & $62 \pm 11$ & $36 \pm 14$ & $\frac{21 \pm 11}{51 \pm 21}$ & $29 \pm 2$ & & $\frac{29 \pm 14}{47 \pm 17}$ & $36 \pm 14$ & & $\frac{21.0 \pm 6.2}{45.5 \pm 11.0}$ \\
\hline & OFF $\quad 0$ & ON & $26 \pm 10$ & $21 \pm 10$ & $9 \pm 7$ & $34 \pm 12$ & $24 \pm 2$ & $31 \pm 10$ & $35 \pm 18$ & $9 \pm 7$ & $69.6 \pm 21.4$ & $48.3 \pm 10.2$ \\
\hline & ON & OFF & $26 \pm 11$ & $24 \pm 14$ & $12 \pm 6$ & $35 \pm 15$ & & $10 \mathrm{~s}$ & $32 \pm 13$ & & 20 & $26.0 \pm 3.6$ \\
\hline & $\begin{array}{ll}\text { ON } & 0 \\
\end{array}$ & ON & $21 \pm 9$ & $13 \pm 7$ & & $21 \pm 8$ & Anticinatory Postu & $18 \pm 6$ & $23 \pm 13$ & $29 \pm 15$ & $2.8 \pm 0.9$ & $26.0 \pm 10.2$ \\
\hline \multirow[t]{3}{*}{ Effects of LD } & No change & & $\begin{array}{l}\text { APAs duration\&amplitude } \\
\text { Stance \& swing leg } \\
\text { shear forces } \\
\text { CoP fP \& }\end{array}$ & & & & Anticipatory Postu & IraA Ajujtionents & & & & \\
\hline & Increase & & & & & CoP AP \& ML D & & $\begin{array}{l}\text { S2 ankle peak Velocity } \\
\text { S2 shoulder amplitude } \\
\text { Velocity of transfer }\end{array}$ & CoP AP \& ML D & & & CoP AP \& ML D \\
\hline & Decrease & & & & & APAs duration & & S2 duration & APAs duration & & & APAs duration \\
\hline \multirow[t]{3}{*}{ Effects of DBS } & No change & & $\begin{array}{l}\text { CoP MLD } \\
\text { APAs duration }\end{array}$ & & & $\begin{array}{l}\text { CoP AP \& ML D } \\
\text { APAs duration }\end{array}$ & \begin{tabular}{l|} 
S1\&S2 duration \\
S1\&S2 CoP D\&Velocity
\end{tabular} & S1 duration & $\begin{array}{l}\text { CoP AP \& ML D } \\
\text { APAs duration }\end{array}$ & & $\begin{array}{l}\text { APAs duration } \\
\text { S2 CoP ML D } \\
\text { S2 CoP Velocity }\end{array}$ & APAs duration \\
\hline & Increase & & Co AP D & $\begin{array}{l}\text { CoP AP \& ML D } \\
\text { TA reinforcement }\end{array}$ & & & $\begin{array}{l}\text { S3 CoP AP Velocity } \\
\text { S3 CoM distance } \\
\text { Resultant CoM-CoP } \\
\text { moment arm }\end{array}$ & $\begin{array}{l}\text { S2 ankle peak Velocity } \\
\text { S2 shoulder amplitude } \\
\text { Velocity of transfer }\end{array}$ & & & $\begin{array}{l}\text { S1 CoP AP D } \\
\text { S1 CoP Velocity }\end{array}$ & CoP AP \& ML D \\
\hline & Decrease & & $\begin{array}{l}\text { Stance \& swing leg } \\
\text { shear forces }\end{array}$ & APAs duration & & & & S2 duration & & & & \\
\hline \multicolumn{13}{|c|}{ First step execution } \\
\hline \multirow[t]{3}{*}{\begin{tabular}{|l|} 
Effects of LD \\
\end{tabular}} & \multicolumn{2}{|c|}{ No change } & & & $\begin{array}{l}\text { Braking index } \\
\text { TA and Soleus activity }\end{array}$ & & & & & $\begin{array}{l}\text { Braking index } \\
\text { TA and Soleus activity }\end{array}$ & & \\
\hline & \multicolumn{2}{|l|}{ Increase } & & & Length and velocity & Length and Velocity & & & Length and Velocity & Length and Velocity & & $\begin{array}{l}\text { Length and Velocity } \\
\text { Braking index }\end{array}$ \\
\hline & \multicolumn{2}{|l|}{$\begin{array}{l}\text { Decrease } \\
\end{array}$} & & & Fall in the CoM & & & & & Fall in the CoM & & $\begin{array}{l}\text { Double stance duration } \\
\end{array}$ \\
\hline \multirow[t]{3}{*}{ Effects of DBS } & \multicolumn{2}{|c|}{ No change } & Cadence & Length and Velocity & $\begin{array}{l}\text { Stance leg TAactivity } \\
\text { Stance \& swing leg sole }\end{array}$ & Length and Velocity & $\begin{array}{l}\text { Length and Velocity } \\
\text { Var } \\
\text { Time Var }\end{array}$ & & Length and Velocity & $\begin{array}{l}\text { Length and Velocity } \\
\text { TA and Soleus activity }\end{array}$ & & $\begin{array}{l}\text { Length and Velocity } \\
\text { Braking Index }\end{array}$ \\
\hline & \multirow{2}{*}{\multicolumn{2}{|c|}{ Increase }} & Velocity & & $\begin{array}{l}\text { Length and velocity } \\
\text { Braking index } \\
\text { Stance leg soleus activity }\end{array}$ & & $\begin{array}{l}\text { Length and Velocity } \\
\text { (higher with } 60 \mathrm{~Hz} \text { vs > } \\
100 \mathrm{~Hz} \text { STN-DBS) }\end{array}$ & & & $\begin{array}{l}\text { Braking index } \\
\text { Stance leg soleus activity }\end{array}$ & & \\
\hline & & & & & Fall in the CoM & & & & & & CoP Velocity & Double stance duration \\
\hline
\end{tabular}

Values are mean \pm SD or mean (range); AP: anteroposterior; APAs: anticipatory postural adjustments; CoP: centre of foot pressure; CoM: centre of mass; D: displacement; DBS: deep brain stimulation; F:

frequency; LD: levodopa; ML: mediolateral; STN: subthalamic nucleus. An increase of the APAs amplitude, CoP displacements, velocities, cadence, braking index and lower limbs muscles activities and angles means an improvement in the spatiotemporal and kinematics parameters of gait initiation. An increase of the APAs duration and double stance duration means an aggravation of gait initiation. 
Table 3. Effects of subthalamic nucleus deep brain stimulation on neurophysiological parameters of gait in PD patients

\begin{tabular}{|c|c|c|c|c|c|c|c|c|c|c|c|c|c|c|c|c|}
\hline & & \begin{tabular}{|l} 
Allert et al. \\
2001
\end{tabular} & $\begin{array}{l}\text { Faist et al., } \\
2001\end{array}$ & $\begin{array}{l}\text { Stolze et al., } \\
2001\end{array}$ & $\begin{array}{l}\text { Xie et al., } \\
2001\end{array}$ & $\begin{array}{l}\text { Ferrarin et al., } \\
2002\end{array}$ & $\begin{array}{l}\text { Bastian et al., } \\
2003\end{array}$ & $\begin{array}{l}\text { Krystkowiak et } \\
\text { al., 2003 }\end{array}$ & $\begin{array}{l}\text { Ferrarin et al., } \\
2005\end{array}$ & $\begin{array}{l}\text { Liu et al., } \\
2005\end{array}$ & $\begin{array}{l}\text { Lubik et al., } \\
2006\end{array}$ & $\begin{array}{l}\text { Hausdorff et } \\
\text { al., 2009 }\end{array}$ & $\begin{array}{l}\text { Johnsen et al., } \\
2009 \& 2010\end{array}$ & $\begin{array}{l}\text { Cantiniaux et } \\
\text { al., 2011 }\end{array}$ & $\begin{array}{l}\text { McNeely et al., } \\
2011\end{array}$ & $\begin{array}{l}\text { Vallabhajosula } \\
\text { et al., } 2015\end{array}$ \\
\hline \multicolumn{2}{|c|}{\begin{tabular}{|l} 
n. of patients \\
\end{tabular}} & 8 & 8 & 9 & 10 & 4 & 6 & 10 & 10 & 11 & 12 & 13 & & & & \\
\hline \multicolumn{2}{|c|}{\begin{tabular}{|l|} 
Age (yrs) \\
Disease duration (yrs)
\end{tabular}} & $57 \pm 3$ & $48 \pm 7$ & $56 \pm 7$ & $56 \pm 10$ & $56 \pm 3$ & $54 \pm 13$ & $57 \pm 8$ & $52-68$ & $54(41-66)$ & $62 \pm 8$ & $64 \pm 9$ & $61(41-69)$ & $65 \pm 5$ & $62 \pm 9$ & $62 \pm 9$ \\
\hline Disease dur & ation (yrs) & $12 \pm 5$ & $13 \pm 7$ & $13 \pm 5$ & $13 \pm 5$ & $19 \pm 6$ & & $13 \pm 5$ & $17 \pm 6$ & $13 \pm 5$ & & $13 \pm 6$ & $13 \pm 4$ & $13 \pm 4$ & $15 \pm 6$ & $14 \pm 4$ \\
\hline \multicolumn{2}{|c|}{$\begin{array}{l}\text { Time after surgery } \\
\text { (months) }\end{array}$} & 3 & $15 \pm 11$ & 3 & $6(3-36)$ & $11 \pm 3$ & $8 \pm 2$ & 3 & $10 \pm 7$ & $16 \pm 10$ & $23 \pm 13$ & $12 \pm 7$ & $19(12-30)$ & $10 \pm 7$ & & $39 \pm 24$ \\
\hline \multirow{4}{*}{$\begin{array}{l}\text { Before } \\
\text { surgery } \\
\text { With STN- } \\
\text { DBS }\end{array}$} & $\begin{array}{l}\text { LD DBS } \\
\text { OFF - } \\
\text { ON - }\end{array}$ & $\begin{array}{l}X \\
X\end{array}$ & & $\begin{array}{l}X \\
X \\
\end{array}$ & & & & $\begin{array}{l}x \\
x \\
\end{array}$ & & $\begin{array}{l}X \\
x \\
\end{array}$ & & & & & $\begin{array}{l}X \\
x \\
\end{array}$ & \\
\hline & $\overline{\text { OFF OFF }}$ & & $\mathrm{X}$ & $\mathrm{X}$ & $\mathrm{X}$ & $\mathrm{X}$ & $\mathrm{X}$ & & $\mathrm{X}$ & $\mathrm{x}$ & $\mathrm{X}$ & $\mathrm{X}$ & $\mathrm{X}$ & $\mathrm{x}$ & $\mathrm{X}$ & $\mathrm{x}$ \\
\hline & 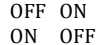 & $\mathrm{x}$ & $\begin{array}{l}X \\
X\end{array}$ & $\mathrm{x}$ & $\begin{array}{l}X \\
X\end{array}$ & $\mathrm{x}$ & $\mathrm{x}$ & $\mathrm{x}$ & $\begin{array}{l}\mathrm{X} \\
\mathrm{X}\end{array}$ & $\begin{array}{l}\mathrm{X} \\
\mathrm{x}\end{array}$ & $\begin{array}{l}\mathrm{X} \\
\mathrm{x}\end{array}$ & $\begin{array}{l}X \\
x\end{array}$ & $\mathrm{x}$ & $\begin{array}{l}\mathrm{X} \\
\mathrm{x}\end{array}$ & $\mathrm{x}$ & $\mathrm{x}$ \\
\hline & ON ON & & $\mathrm{x}$ & $\mathrm{x}$ & $\mathrm{x}$ & & & $\mathrm{x}$ & $\mathrm{x}$ & $\mathrm{x}$ & $\mathrm{x}$ & $\mathrm{x}$ & & $\mathrm{x}$ & & \\
\hline \multirow[t]{4}{*}{ UPDRSIII } & $\begin{array}{l}\text { OFF - } \\
\text { ON - }\end{array}$ & $\begin{array}{l}17 \pm 4 \\
6 \pm 5 \\
\end{array}$ & $\begin{array}{l}50 \pm 15 \\
8 \pm 3\end{array}$ & $\begin{array}{l}52 \pm 8 \\
18 \pm 4 \\
\end{array}$ & & & & $\begin{array}{l}52 \pm 16 \\
25 \pm 8\end{array}$ & & $\begin{array}{l}41 \pm 7 \\
26 \pm 11\end{array}$ & & & & & $\begin{array}{l}36 \pm 2 \\
29 \pm 2\end{array}$ & \\
\hline & OFF OFF & $15 \pm 4$ & $49 \pm 16$ & & $43 \pm 13$ & $59 \pm 8$ & $47 \pm 10$ & & $62 \pm 11$ & $19 \pm 9$ & $56 \pm 12$ & $31 \pm 13$ & $38 \pm 13$ & $37 \pm 17$ & & $29 \pm 2$ \\
\hline & OFF ON & $\begin{array}{l}6 \pm 4 \\
0+5\end{array}$ & $14 \pm 7$ & $27 \pm 7$ & $19 \pm 10$ & $18 \pm 8$ & $22 \pm 13$ & $26 \pm 7$ & $21 \pm 10$ & & $31 \pm 5$ & $18 \pm 1$ & $17 \pm 8$ & $16 \pm 13$ & & $24 \pm 2(>100 \mathrm{~Hz})$ \\
\hline & $\begin{array}{ll}\text { ON } & \text { OFF } \\
\text { ON } & \text { ON }\end{array}$ & $\mid \begin{array}{l}9 \pm 5 \\
6+5\end{array}$ & $\begin{array}{l}7 \pm 3 \\
4+2\end{array}$ & $20+7$ & $\begin{array}{l}19 \pm 14 \\
13+9\end{array}$ & & & $14+5$ & $\begin{array}{l}24 \pm 14 \\
13+7\end{array}$ & $18 \pm 8$ & $\begin{array}{l}21 \pm 5 \\
20+5\end{array}$ & $\begin{array}{l}20 \pm 12 \\
9+5\end{array}$ & & $\begin{array}{l}11 \pm 8 \\
9+7\end{array}$ & & $25 \pm 2(60 \mathrm{~Hz})$ \\
\hline \multirow[t]{3}{*}{$\begin{array}{l}\text { Effects of } \\
\text { LD }\end{array}$} & No change & $0 \pm 0$ & $\begin{array}{l}\text { Cadence (\&Var) } \\
\text { Stride Length Var } \\
\text { Velocity Var } \\
\text { SL Support }\end{array}$ & Cadence & $\begin{array}{l}\text { Cadence } \\
\text { Stride Time } \\
\text { SL\&DL Support }\end{array}$ & & & 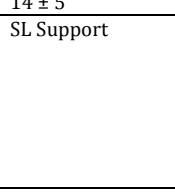 & $\begin{array}{l}\text { Cadence } \\
\text { SL/DL Support } \\
\text { Pelvis yaw ROM } \\
\text { Trunk pitch ROM \& } \\
\text { mean } \\
\text { Ankle moment \& power } \\
\text { peak }\end{array}$ & $\begin{array}{l}\text { Cadence } \\
\text { Velocity }\end{array}$ & $\begin{array}{l}\text { Cadence } \\
\text { Step Length } \\
\text { SL Support } \\
\text { Asymmetry } \\
\text { Index }\end{array}$ & $\begin{array}{l}\text { ly } \pm 5 \\
\text { Cadence } \\
\text { Stride Time } \\
\text { (\&Var) } \\
\text { SL Support Var }\end{array}$ & & Cadence & & \\
\hline & Increase & & $\begin{array}{l}\text { Velocity } \\
\text { Stride Length } \\
\text { Swing Velocity } \\
\text { Hip, knee, ankle } \\
\text { ROM }\end{array}$ & $\begin{array}{l}\text { Velocity } \\
\text { Stride } \\
\text { Length } \\
\text { Step Height } \\
\text { Hip, knee, } \\
\text { ankle ROM }\end{array}$ & $\begin{array}{l}\text { Velocity } \\
\text { Stride Length }\end{array}$ & & & $\begin{array}{l}\text { Velocity } \\
\text { Cadence } \\
\text { Stride\&Step } \\
\text { Length } \\
\text { SL/DL ratio }\end{array}$ & $\begin{array}{l}\text { Velocity } \\
\text { Stride Length } \\
\text { Hip, knee, ankle ROM } \\
\text { Pelvis tilt\&roll ROM } \\
\text { Trunk rolllyaw ROM } \\
\text { Hip moment\&power } \\
\text { peak }\end{array}$ & & Velocity & $\begin{array}{l}\text { Velocity } \\
\text { Stride Length } \\
\text { SL Support }\end{array}$ & & $\begin{array}{l}\text { Velocity } \\
\text { Step Length }\end{array}$ & & \\
\hline & Decrease & & DL Support & & & & & $\begin{array}{l}\text { DL Support } \\
\text { Stride\&Step Time }\end{array}$ & & & $\begin{array}{l}\text { Step Time } \\
\text { DL Support }\end{array}$ & & & & & \\
\hline \multirow[t]{3}{*}{$\begin{array}{l}\text { Effects of } \\
\text { STN-DBS }\end{array}$} & No change & \begin{tabular}{|l|} 
Cadence \\
Step Time \\
Asymmetry \\
Index \\
DL Support \\
Var \\
\end{tabular} & $\begin{array}{l}\text { Cadence } \\
\text { Stride Length Var } \\
\text { Velocity Var } \\
\text { SL Support }\end{array}$ & Cadence & $\begin{array}{l}\text { Cadence } \\
\text { Stride Time } \\
\text { SL\&DL Support }\end{array}$ & $\begin{array}{l}\text { Cadence } \\
\text { SL/DL Support } \\
\text { t Ankle ROM } \\
\text { Pelvis roll ROM } \\
\text { Trunk yaw } \\
\text { ROM }\end{array}$ & $\begin{array}{l}\text { Cadence } \\
\text { Asymmetry Index } \\
\text { SL Support }\end{array}$ & & $\begin{array}{l}\text { Cadence } \\
\text { SL/DL Support } \\
\text { Pelvis roll \& yaw ROM } \\
\text { Trunk-Pelvis roll ROM } \\
\text { Trunk pitch ROM } \\
\text { Hip moment peak } \\
\text { Ankle moment \& power } \\
\text { peak }\end{array}$ & Cadence & $\begin{array}{l}\text { Cadence } \\
\text { Step Length } \\
\text { SL Support }\end{array}$ & $\begin{array}{l}\text { Cadence } \\
\text { Velocity } \\
\text { Stride Length } \\
\text { Stride Time } \\
\text { ( \& Var) } \\
\text { SL Support Var }\end{array}$ & $\begin{array}{l}\text { Cadence } \\
\text { Stride Time }\end{array}$ & Cadence & & $\begin{array}{l}\text { Cadence Var } \\
\text { Velocity Var } \\
\text { Stride Time } \\
\text { Stride Length } \\
\text { SL\&DL Support } \\
\text { (\& Var) }\end{array}$ \\
\hline & Increase & $\begin{array}{l}\text { Velocity } \\
\text { Step Length } \\
\text { SL Support } \\
\text { SL/DL } \\
\text { Support }\end{array}$ & $\begin{array}{l}\text { Velocity } \\
\text { Stride Length } \\
\text { Swing Velocity } \\
\text { Hip, knee, ankle } \\
\text { ROM }\end{array}$ & $\begin{array}{l}\text { Velocity } \\
\text { Stride } \\
\text { Length } \\
\text { Step Height } \\
\text { Hip, knee, } \\
\text { ankle ROM } \\
\end{array}$ & $\begin{array}{l}\text { Velocity } \\
\text { Stride Length } \\
\text { Step Height }\end{array}$ & $\begin{array}{l}\text { Velocity } \\
\text { Stride Length } \\
\text { Hip\&Knee } \\
\text { ROM } \\
\text { Trunk pitch \& } \\
\text { roll ROM } \\
\end{array}$ & $\begin{array}{l}\text { Velocity } \\
\text { Stride Length }\end{array}$ & $\begin{array}{l}\text { Velocity } \\
\text { Cadence } \\
\text { Stride T \& Length } \\
\text { Step T \& Length } \\
\text { SL Support }\end{array}$ & $\begin{array}{l}\text { Velocity } \\
\text { Stride Length } \\
\text { Hip, knee, ankle ROM } \\
\text { Trunk-Pelvis yaw ROM } \\
\text { Hip moment peak }\end{array}$ & Velocity & Velocity & SL Support & $\begin{array}{l}\text { Velocity } \\
\text { Step Length } \\
\text { Stride Length } \\
\text { Hip, knee, } \\
\text { ankle ROM }\end{array}$ & $\begin{array}{l}\text { Velocity } \\
\text { Step Length }\end{array}$ & $\begin{array}{l}\text { Velocity } \\
\text { Stride Length }\end{array}$ & $\begin{array}{l}\text { Velocity } \\
\text { Step Length }\end{array}$ \\
\hline & Decrease & $\begin{array}{l}\text { Step T Var } \\
\text { SL Support } \\
\text { Var }\end{array}$ & DL Support & Stride Var & & & & DL Support & & & $\begin{array}{l}\text { Step Time } \\
\text { Asymmetry } \\
\text { Index } \\
\text { DL Support } \\
\end{array}$ & & $\begin{array}{l}\text { DL Support } \\
\text { Asymmetry } \\
\text { Index }\end{array}$ & & & \\
\hline
\end{tabular}

Values are mean \pm SD or mean (range); DL: double-limb; SL: single-limb; Var: variability; ROM: range of motion, DBS: deep brain stimulation; LD: levodopa; TN: subthalamic nucleus; UB: upper body; An increase

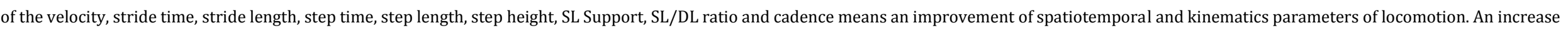
of the double limb support and asymmetry index means an aggravation of locomotion. 
Table 4. Effects of deep brain stimulation of the GPi and PPN on neurophysiological parameters

of gait in PD patients

\begin{tabular}{|c|c|c|c|c|c|c|c|}
\hline \multicolumn{3}{|l|}{ Target } & $\begin{array}{l}\text { Allert et al., } 2001 \\
\text { GPi }\end{array}$ & $\begin{array}{l}\text { Defebvre et al., } \\
2002 \\
\text { GPi }\end{array}$ & \begin{tabular}{|l|} 
Moreau et al., \\
2009 \\
Bilateral PPN* \\
\end{tabular} & \begin{tabular}{|l|} 
Peppe et al., \\
2010 \\
Bilateral PPN* \\
\end{tabular} & \begin{tabular}{|l|} 
Mazzone et al., \\
2014 \\
Unilateral PPN \\
\end{tabular} \\
\hline \multicolumn{3}{|c|}{ n. of patients } & 10 & 7 & 4 & 5 & 10 \\
\hline \multicolumn{3}{|l|}{ Age (yrs) } & $55 \pm 10$ & $58 \pm 11$ & & $58 \pm 9$ & $60 \pm 7$ \\
\hline \multicolumn{3}{|c|}{ Disease duration (yrs) } & $11 \pm 3$ & $15 \pm 3$ & & $16 \pm 10$ & \\
\hline \multicolumn{3}{|c|}{$\begin{array}{l}\text { Time after surgery } \\
\text { (months) }\end{array}$} & 3 & 3 & & 3 & 12 \\
\hline \multirow[b]{2}{*}{$\begin{array}{l}\text { Before } \\
\text { surgery }\end{array}$} & LD & DBS & & & & & \\
\hline & $\begin{array}{l}\text { OFF } \\
\text { ON }\end{array}$ & $\begin{array}{l}- \\
-\end{array}$ & $\begin{array}{l}\mathrm{X} \\
\mathrm{X}\end{array}$ & & & & \\
\hline With DBS & $\begin{array}{l}\text { OFF } \\
\text { OFF } \\
\text { ON } \\
\text { ON }\end{array}$ & $\begin{array}{l}\text { OFF } \\
\text { ON } \\
\text { OFF } \\
\text { ON }\end{array}$ & $\begin{array}{l}\mathrm{X} \\
\mathrm{X}\end{array}$ & $\begin{array}{l}X \\
X \\
X \\
X\end{array}$ & $\begin{array}{l}X \\
X \\
X \\
X\end{array}$ & $\begin{array}{l}\mathrm{X} \\
\mathrm{X} \\
\mathrm{X} \\
\mathrm{X}\end{array}$ & $\mathrm{X}$ \\
\hline \multirow[t]{2}{*}{ UPDRS III } & $\begin{array}{l}\mathrm{OFF} \\
\mathrm{ON} \\
\end{array}$ & $\begin{array}{l}- \\
-\end{array}$ & \begin{tabular}{|l|}
$17 \pm 4.5$ \\
$6 \pm 5.5$ \\
\end{tabular} & $\begin{array}{l}50 \pm 6 \\
19 \pm 6 \\
\end{array}$ & & & $5.3 \pm 3.0$ \\
\hline & $\begin{array}{l}\mathrm{OFF} \\
\text { OFF } \\
\text { ON } \\
\text { ON }\end{array}$ & $\begin{array}{l}\text { OFF } \\
\text { ON } \\
\text { OFF } \\
\text { ON }\end{array}$ & & $\begin{array}{l}31 \pm 10 \\
16 \pm 8\end{array}$ & 28 & $\begin{array}{l}68 \pm 5 \\
43 \pm 9 \\
37 \pm 10 \\
25 \pm 9 \\
\end{array}$ & $\begin{array}{l}70 \pm 21 \\
28 \pm 9\end{array}$ \\
\hline \multirow[t]{3}{*}{$\begin{array}{l}\text { Effects of } \\
\text { LD }\end{array}$} & \multicolumn{2}{|c|}{ No change } & & Cadence & & Mean velocity & \\
\hline & \multicolumn{2}{|c|}{ Increase } & & $\begin{array}{l}\text { Velocity } \\
\text { Stride T } \\
\text { Stride Length } \\
\text { Step Length } \\
\text { SL Support }\end{array}$ & & $\begin{array}{l}\text { Hip, Knee, Arm } \\
\text { \&Elbow angles }\end{array}$ & \\
\hline & \multicolumn{2}{|c|}{ Decrease } & & DL Support & & & \\
\hline \multirow[t]{3}{*}{$\begin{array}{l}\text { Effects of } \\
\text { DBS }\end{array}$} & \multicolumn{2}{|c|}{ No change } & \begin{tabular}{|l} 
Cadence \\
Step Time\&Length \\
Asymmetry Index \\
SL\&DL Support \\
(\&Var) \\
SL/DL Support \\
\end{tabular} & SL Support & \begin{tabular}{|l|} 
Cadence \\
Mean velocity \\
Step Time\&Length \\
SL\&DL Support
\end{tabular} & $\begin{array}{l}\text { Mean velocity } \\
\text { Stride\&Step Length } \\
\text { SL\& DL Support } \\
\text { SL/DL Support } \\
\text { Hip, Knee, Ankle, } \\
\text { ROM }\end{array}$ & $\begin{array}{l}\text { Step Width } \\
\text { SL\& DL Support } \\
\text { IL pelvis tilt ROM } \\
\text { Hip, knee ROM }\end{array}$ \\
\hline & \multicolumn{2}{|c|}{ Increase } & Velocity & $\begin{array}{l}\text { Velocity } \\
\text { Cadence } \\
\text { Stride Time\&Length } \\
\text { Step Length }\end{array}$ & & & $\begin{array}{l}\text { Velocity } \\
\text { Cadence } \\
\text { Stride Length }\end{array}$ \\
\hline & \multicolumn{2}{|c|}{ Decrease } & & DL Support & & & \\
\hline
\end{tabular}

Values are mean \pm SD or mean (range); DBS: deep brain stimulation; DL: double limbs; IL:

interlimb; T: time, SL: single limb; ROM: range of motion; GPi: internal part of the globus pallidus; PPN: pedunculopontine nucleus. An increase of the stride time and length, velocity, step length,

SL Support and ROM means an improvement of gait parameters.. An increase of the DL Support and Step Width means an aggravation.* In this study patients were previously operated for STNDBS. 


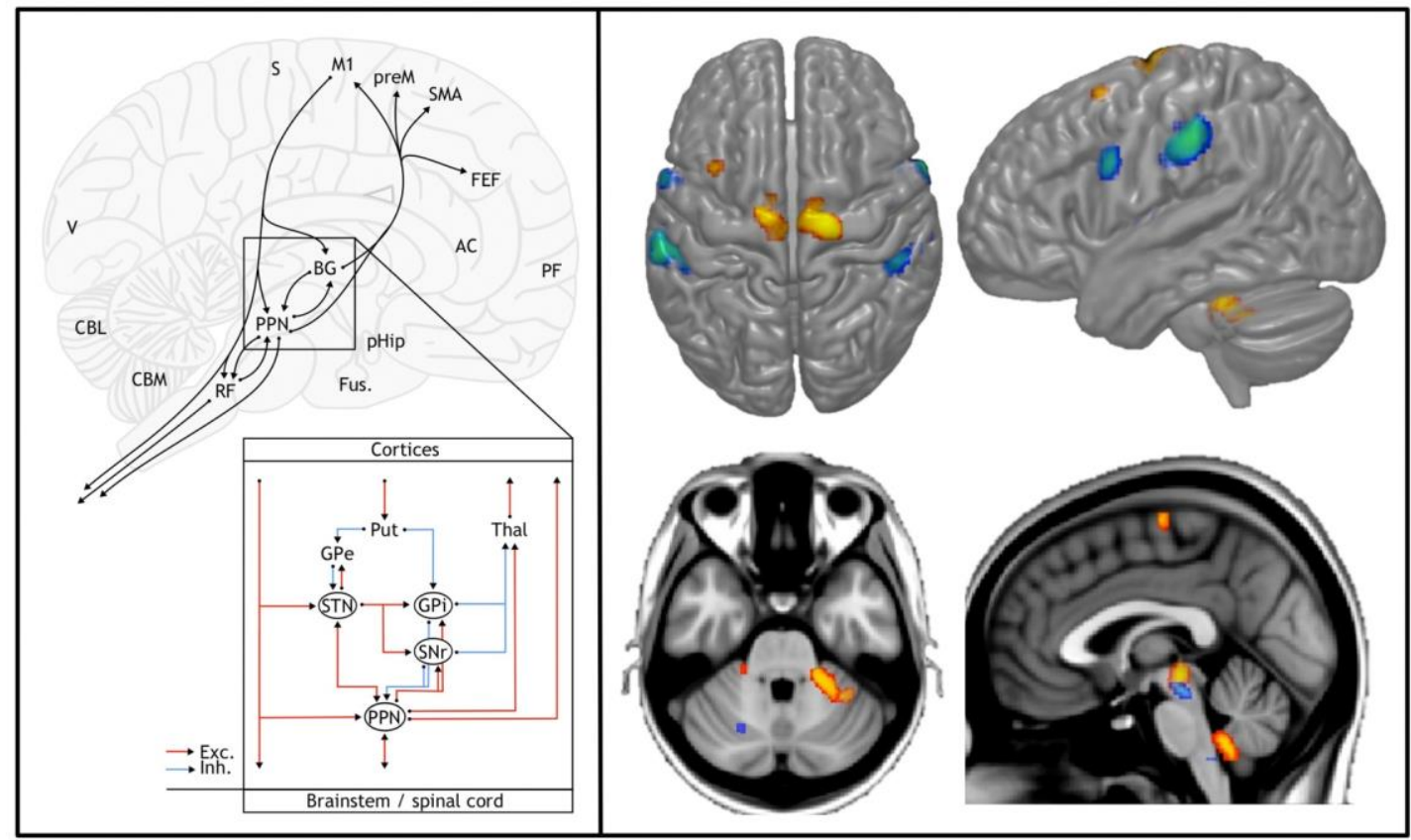

Figure 1 
OFF LD

to H0F01 FCF02 FC2

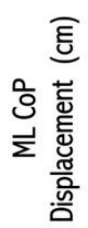

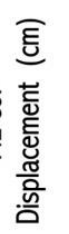

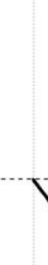

ON LD

to HOF01 FC F02 $\mathrm{FC2}$

ON STN-DBS

to $\mathrm{HOF01}$ FCFO2 $\mathrm{FC2}$

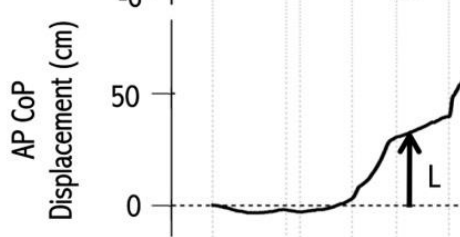

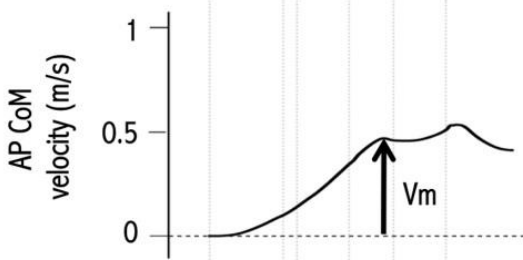

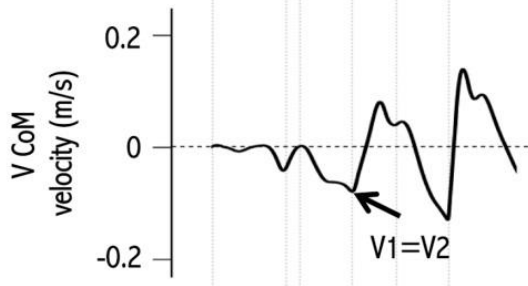

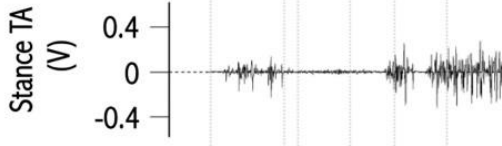

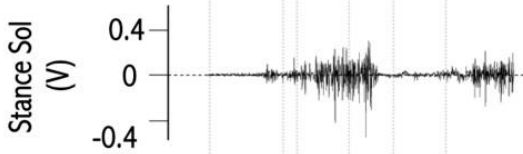

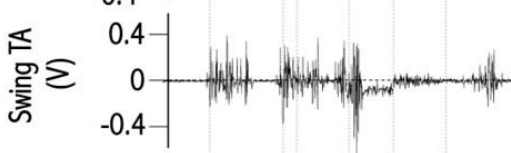

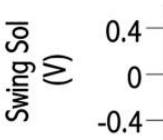
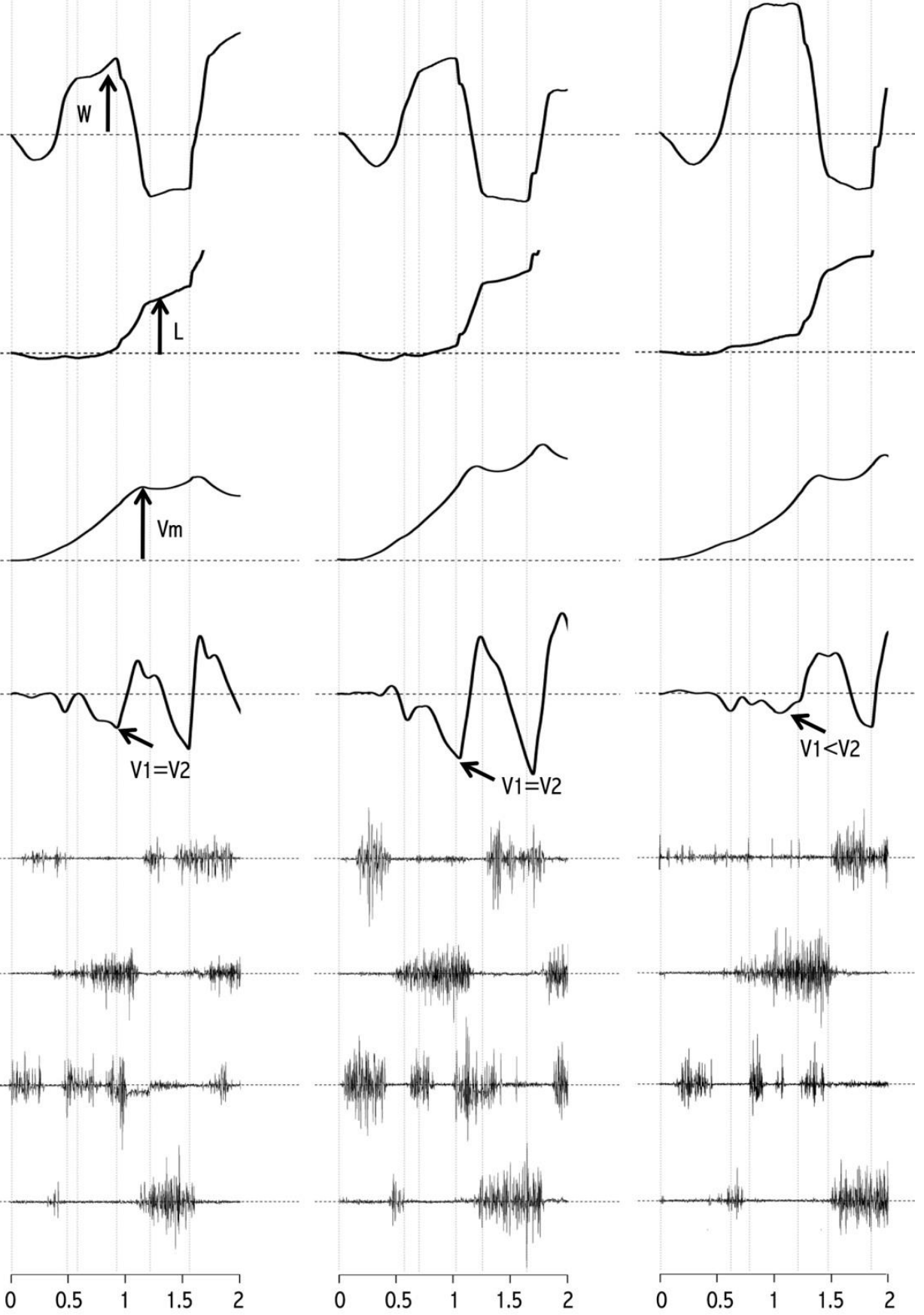

Figure 2
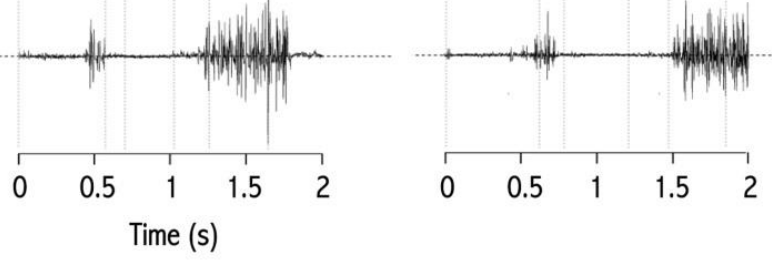